\title{
KERAJAAN NEGARA DAHA DI TEPIAN SUNGAI NEGARA, KALIMANTAN SELATAN
}

\section{Sunarningsih}

\author{
Balai Arkeologi Banjarmasin, Jalan Gotong Royong II, RT 03/06, Banjarbaru 70711, Kalimantan Selatan; \\ Telepon (0511) 4781716; Facsimile (0511) 4781716; email: asihwasita@yahoo.com
}

\begin{abstract}
Abstrak.Toponim Negara di wilayah Kabupaten Hulu Sungai Selatan, Propinsi Kalimantan Selatan banyak dikaitkan dengan keberadaan Kerajaan Negara Daha dalam Hikayat Banjar. Hasil penelitian di sepanjang aliran Sungai Negara yang dilakukan oleh Balai Arkeologi Banjarmasin dengan metode ekskavasi dan survei menghasilkan banyak artefak yang menunjukkan bukti adanya sisa pemukiman kuna di wilayah Negara. Pada saat ini, temuan pemukiman kuna berada pada dua wilayah kecamatan, yaitu Kecamatan Daha Utara dan Daha Barat. Penelitian ini bertujuan membahas hubungan antara data arkeologis yang ditemukan di situs pemukiman kuna dengan keberadaan Kerajaan Negara Daha. Metode yang digunakan adalah deskriptif dengan penalaran induktif. Analisis terhadap data artefaktual menggunakan analisis morfologi, berdasarkan bentuk, bahan, dan jumlahnya. Hasil analisis selanjutnya akan diperbandingkan untuk mengetahui kronologinya. Studi pustaka dilakukan untuk mengumpulkan teori dan referensi yang mendukung dalam interpretasi. Dari hasil analisis dan kajian pustaka dapat diasumsikan bahwa wilayah Negara pada abad ke-14 sudah dihuni oleh sebuah komunitas masyarakat dalam jumlah yang besar dan sudah menguasai teknologi yang cukup maju, sehingga dapat melakukan berbagai aktivitas yang menggambarkan sebuah kehidupan masyarakat yang kompleks. Masuknya komoditi dari luar menjadi salah satu petunjuk adanya aktivitas perdagangan, yang juga menjadi sebuah indikasi bahwa pemenuhan terhadap kebutuhan sehari-hari sudah tercukupi (masyarakat yang makmur)
\end{abstract}

Kata kunci: Negara Daha, Sungai Negara, pemukiman kuna, gerabah, manik-manik, artefak kayu, keramik China

\begin{abstract}
THE ANCIENT KINGDOM OF NEGARA DAHA ON THE BANKS OF NEGARA RIVER, SOUTH KALIMANTAN Toponym of Negara in the district of Hulu Sungai Selatan, South Kalimantan Province is associated with the presence of the Negara Daha Kingdom mentioned in Hikayat Banjar. Archaeological data from the river bank of Negara river collected by the Archaeological Research Center of Banjarmasin (Balai Arkeologi Banjarmasin) during excavation and survey give the evidence of ancient settlements. The findings of ancient settlement located in two districts, namely District of North Daha and West Daha. The objective of research discusses the relationship between archaeological data found in the ancient settlement sites and the presence of the kingdom of Negara Daha. The reserach method used in this study is descriptive with inductive reasoning. The artefacts will be analized by morphological analysis, based on shape, material, and quantity. The analysis results will be compared to determine its chronology. Literature will be searched to gain some theories and references that support the interpretation. The results show that the Negara territory during the 14th century was inhabited by a large numbers of people (communities), and had advanced technology. Therefore, they performed a variety of activities that describe a complex society. The existence of commodities from outside is being one indication of trading activity, which also became an indication that their daily needs have been fulfilled (affluent society)
\end{abstract}

Keywords: Negara Daha, Negara River, ancient settlements, ancient pottery, ancient beads, wooden artefacts, Chinese ceramics

\section{A. Pendahuluan}

Salah satu kabupaten di wilayah Propinsi Kalimantan Selatan yang memiliki satu wilayah yang dikenal dengan sebutan Negara adalah Kabupaten Hulu Sungai Selatan. Wilayah Negara tersebut terbagi menjadi tiga buah kecamatan, yaitu Kecamatan Daha Utara, Daha Selatan, dan Daha Barat. Nama Negara dan Daha (yang menjadi nama administratif kecamatan) sangat menarik untuk dilihat kembali, apakah sebenarnya latar belakang penyebutan kedua 
nama tersebut oleh masyarakat. Toponim biasanya mempunyai makna tersendiri bagi masyarakat yang hidup di sekitarnya. Toponim tersebut diyakini berkaitan dengan keberadaan sebuah kerajaan kuna, yaitu Kerajaan Negara Daha.

Wilayah Negara, tepatnya berada di daerah pertemuan sungai (tumbukan banyu) yang mengarah ketiga wilayah yang berbeda, dan di sepanjang sungai tersebut banyak terdapat situs pemukiman kuna (Peta 1). Pada masa lalu tepat di tengah pertemuan sungai tersebut terdapat sebuah arus yang berputar sangat kencang, tidak ada satu perahu pun yang berani melintas di dekatnya. Pada saat ini, putaran arus tersebut sudah semakin kecil dan lemah, meskipun demikian keberadaannya masih bisa terlihat. Posisi Negara yang berada pada persimpangan sungai memang sangat strategis, yaitu tempat bertemunya arus transportasi dari hulu ke hilir dan sebaliknya.

Keberadaan situs di Negara diketahui dari informasi penduduk tentang temuan kapal kayu di Dukuh (Desa Penggandingan). Penduduk pernah melihat bentuk salung (haluan kapal) yang muncul pada musim kemarau. Penduduk juga pernah mengangkat bagian lunas kapal yang memiliki panjang 16 meter, dan menyimpannya di kantor Koramil (eks Kawedanan Negara), tetapi kemudian kantor tersebut terbakar termasuk lunas kapal tersebut. Selain itu, penggalian liar oleh penduduk banyak dilakukan di Desa Tanjung Selor, Bajayau, Bajayau Lama, dan sekitarnya. Masyarakat menemukan sisa pemukiman kuna yang antara lain berupa, perhiasan emas, peralatan pertanian dari kayu, dayung kayu, manik kaca, dan fragmen gerabah.

Berdasarkan informasi tersebut, sebuah tim dari Balai Arkeologi Banjarmasin (pada Oktober 2006) dibentuk untuk meninjau lokasi temuan. Hasil survei menunjukkan bahwa banyak terdapat sebaran fragmen keramik asing dan gerabah di permukaan tanah, sedangkan keberadaan kapal tidak terlihat karena tertimbun longsoran tanah. Selain itu, juga terdapat kegiatan penggalian liar yang dilakukan oleh masyarakat sekitar. Berdasarkan hasil peninjauan disimpulkan bahwa di daerah Negara terdapat pemukiman kuna dan perlu ditindaklanjuti dengan sebuah penelitian yang lebih serius.

Selanjutnya, penelitian arkeologi wilayah Negara dilakukan pada tahun 2007 (Sunarningsih 2007), di dua wilayah kecamatan, yaitu Kecamatan Daha Utara dan Daha Barat, Kabupaten Hulu Sungai Selatan. Ada lima desa yang diteliti, yaitu Desa Penggandingan, Desa Tambak Bitin (keduanya masuk wilayah Kecamatan Daha Utara), Desa Tanjung Selor, Desa Bajayau, dan Desa Bajayau Lama (ketiganya masuk wilayah Daha
Barat. Survei lanjutan dilakukan pada 2013, untuk melakukan inventarisasi data artefaktual yang ditemukan oleh masyarakat setempat.

Artikel ini membahas hubungan antara data arkeologis pada situs pemukiman kuna di sepanjang Sungai Negara dengan keberadaan Negara Daha pada abad ke-14 M. Apakah data arkeologi tersebut bisa mendukung data tertulis dan keyakinan masyarakat terhadap keberadaan Kerajaan Negara Daha di wilayah Negara? Metode penelitian yang digunakan adalah deskriptif dengan penalaran induktif. Data artefaktual akan dianalisis dengan menggunakan analisis morfologi, berdasarkan bentuk, bahan, dan jumlah (Harkantiningsih, dkk 1999). Selanjutnya, akan diperbandingkan data tersebut sehingga dapat diketahui kronologinya. Tujuan dari studi ini adalah membuktikan bahwa Kerajaan Negara Daha memang berada di wilayah Negara, Kecamatan Daha Utara dan Daha Barat berdasarkan data arkeologis yang ditemukan. Dengan demikian, diharapkan tulisan ini dapat memberi informasi baru bagi penyusunan sejarah kerajaan kuna di wilayah Kalimantan Selatan.

\section{B. Terbentuknya Negara Suku (Chiefdoms) dan Negara Awal (Early State)}

Dalam proses kehidupan manusia, perubahan selalu terjadi baik dalam aspek ideologi, teknologi, maupun sosial. Pembagian kehidupan manusia pada masa lalu terdiri atas masa prasejarah dan masa sejarah, yang didasarkan pada belum dan mulai dikenalnya tulisan. Kronologi kehidupan pada masa prasejarah di Indonesia disusun berdasarkan pada tingkat teknologi yang dikuasai dan juga jenis mata pencaharian yang dilakukan. Pembabakan tersebut dibagi menjadi masa berburu dan meramu tingkat sederhana, berburu dan meramu tingkat lanjut, bercocok tanam, dan masa perundagian (Soejono 1981, 14-6). Pada masa perundagian, yaitu mulai dikenal dan dikuasainya berbagai macam keahlian, seperti pembuatan alat logam, ukiran, dan kerajinan lainnya. Penguasaan terhadap teknologi yang lebih maju tentunya bisa disebabkan oleh adanya inovasi dan juga adanya interaksi dengan dunia luar. Dalam proses interaksi terjadilah pertukaran barang, dan informasi yang terdiri atas ide, simbol, kreativitas, aspirasi, dan nilai (Renfrew dan Paul Bahn 2008, 387). Adanya interaksi itu juga yang membawa perubahan kehidupan masyarakat, yaitu mengenal tulisan, yang berarti dimulailah masa sejarah. Masa sejarah di Indonesia dimulai sejak masuknya pengaruh India yang mengenalkan kepercayaan baru sekaligus mengenalkan tulisan. 


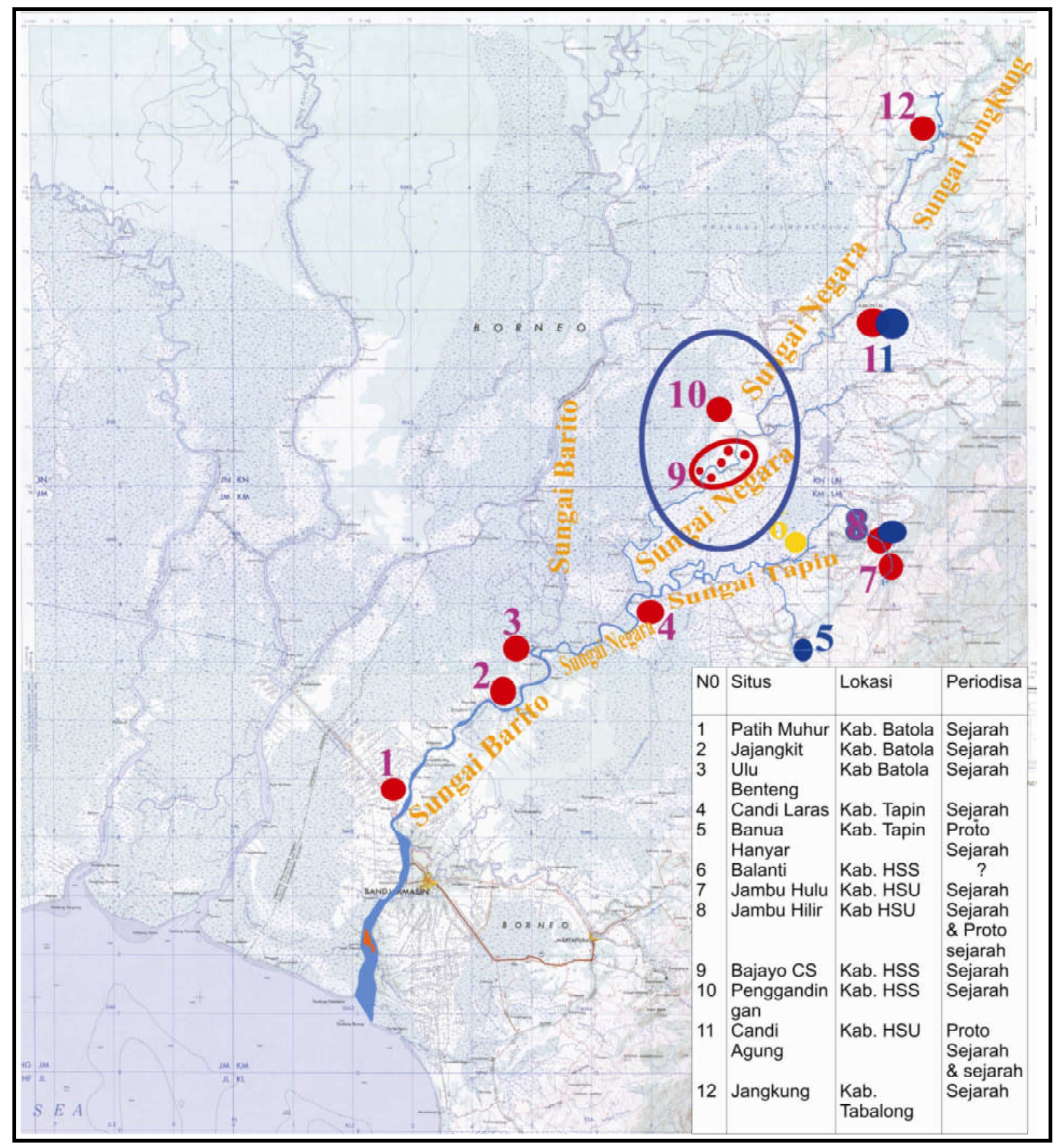

Peta 1. Wilayah Negara (lingkaran biru) dan situs pemukiman lain di sepanjang aliran Sungai Negara (sumber: Sunarningsih, 2012 dengan sedikit perubahan).

Proses perubahan secara sosial kemasyarakatan juga terjadi pada kehidupan masyarakat tersebut. Para ahli mengklasifikasi masyarakat dalam empat tingkatan (Renfrew dan Paul Bahn 2006, 191-195), yaitu kelompok yang hidup berpindah (bands), keluarga besar (tribe), negara suku (chiefdoms), dan negara (state). Kehidupan pada masa prasejarah meliputi tiga tingkatan sosial masyarakat yang pertama, yaitu bands, tribe, dan chiefdoms. Negara (state) terbentuk pada saat masyarakat sudah mulai mengenal tulisan. Dalam sebuah negara (state), memiliki populasi yang besar, mengenal lembaga formal pemerintahan, terdapat tingkatan sosial dalam masyarakat, mengenal hukum dan pekerjaan administrasi. Dalam proses pembentukannya, negara awal atau kerajaan awal muncul terlebih dahulu yang selanjutnya berkembang menjadi sebuah negara/kerajaan. Perbedaan antara negara awal dan negara dapat dilihat berdasarkan masa kekuasaan, luas daerah kekuasaannya, dan adanya penyatuan dua atau lebih daerah inti (core) dari beberapa negara awal (Kulke1990, 5-8). Dalam sebuah negara awal terdapat sebuah wilayah yang menjadi pusat pemerintahan di mana raja dan keluarganya tinggal, serta wilayah penyangga 
(periphery) yang ditempati oleh rakyat dengan segala aktivitas yang dapat mendukung kehidupan sebuah kerajaan. Apabila daerah inti (core) pada sebuah negara awal dapat ditaklukkan dengan sendirinya wilayah penyangga juga akan mengikuti.

Keberadaan sebuah negara awal di Kalimantan yang paling tua adalah Kerajaan Kutai yang saat ini berada di Propinsi Kalimantan Timur, tepatnya di tepi Sungai Mahakam. Tujuh buah prasasti yupa (tiang batu) berbahasa Sanskrta dan berhuruf Pallawa ditemukan, dan memberi informasi adanya sebuah kerajaan tertua di Kalimantan dengan yang dipimpin oleh Raja Mulavarman (Poesponegoro, Nugroho Notosusanto 1993, 29-34). Kulke (1991, 5) telah melakukan analisis terhadap prasasti yupa tersebut, dan berpendapat bahwa keraton Raja Mulavarman berada tidak jauh dari tempat yang paling sakral (tempat pemujaan). Keraton tersebut dikelilingi oleh tempat tinggal penduduk dan tanah yang diberikan kepada para Brahmana.

\section{Kerajaan Negara Daha Berdasarkan Data Historis}

Belum ada prasasti yang ditemukan di wilayah Negara hingga saat ini. Sumber tertulis yang menceritakan kerajaan tertua adalah sebuah manuskrip berbahasa Melayu, yaitu Hikayat Banjar. Hikayat Banjar menceritakan tentang keberadaan kerajaan kuna di wilayah Kalimantan Selatan yang dimulai dengan munculnya Kerajaan Nan Sarunai, yang diikuti dengan munculnya Negara Dipa dan Kerajaan Daha (Ras 1990; Ideham 2007, 52). Disebutkan bahwa Kerajaan Nan Sarunai yang masyarakatnya merupakan orang Dayak Maanyan tinggal di daerah yang bernama Sarunai, di sekitar aliran Sungai Tabalong. Selanjutnya, kerajaan ini hilang akibat adanya serangan dari Majapahit pada abad ke14 Masehi. Muncullah sebuah kerajaan baru bernama Negara Dipa. Negara Dipa didirikan oleh Mpu Jatmika yang beribukota di Kuripan dan pelabuhannya di Muara Rampiau (Ras 1990). Pada saat ini, cerita mengenai Mpu Jatmika banyak dikaitkan dengan bangunan candi di daerah Amuntai, yaitu Candi Agung. Wilayah kekuasaan Negara Dipa meliputi beberapa daerah aliran sungai (batang), yaitu antara lain Batang Tabalong, Batang Balangan, Batang Petak, Batang Alai, dan Batang Amandit beserta bukit-bukit di sekitarnya. Mpu Jatmika kemudian digantikan oleh Putri Junjung Buih yang bersuamikan Raden Putra, yang selanjutnya bergelar Pangeran Suryanata. Pada masa kekuasaan Pangeran Suryanata, wilayah kekuasaan Negara Dipa semakin luas, yaitu antara lain Sukadana, Sambas, Batang Lawai, Kotawaringin, Pasir, Kutai, Karasikan, dan Berau. Penguasa Negara Dipa setelah Pangeran Suryanata adalah Suryaganggawangsa, kemudian dilanjutkan oleh Maharaja Carang Lalean. Periode Negara Dipa berakhir pada masa kekuasaan Putri Kalungsu.

Kerajaan Daha diperintah oleh Sekarsungsang yang bergelar Panji Agung Maharaja Sari Kaburangan, dengan pusat kerajaan di Muara Hulak dan pelabuhannya di Muara Bahan. Kekuasan Negara Daha antara lain adalah Sewa Agung, Bunyut, Karasikan, Balitung, Lawai, dan Kotawaringin. Masa pemerintahan Negara Daha berakhir pada akhir masa kekuasaan Raden Sukarama. Raja ini memberi wasiat agar Raden Samudera menggantikan posisinya, tetapi keputusan itu mendapat tentangan dari ketiga anaknya, yaitu Mangkubumi, Tumenggung, dan Bagalung. Selanjutnya Pangeran Tumenggung mengangkat dirinya menjadi raja di Negara Daha. Raden Samudera sebagai pewaris tahta akhirnya melarikan diri dan mendirikan kerajaan di wilayah Banjarmasin. Dengan bantuan dari Kerajaan Demak, Raden Samudera dapat mengambil kembali haknya sebagai raja di Kerajaan Daha. Sejak saat itu, dimulailah kehidupan kerajaan baru yang bercorak Islam, yaitu Kerajaan Banjar (Ideham, dkk. 2007, 66-72)

Sumber tertulis lainnya yang menyebutkan adanya sebuah kerajaan kuna di bawah kekuasaan Majapahit adalah Kitab Negarakretagama (1365). Majapahit telah memiliki negara bawahan yang berada di wilayah Kalimantan, yaitu Kerajaan Tanjungpuri. Wilayah Tanjungpuri meliputi, wilayah barat yaitu Brune dan Sukadana (Kalimantan Barat), wilayah selatan yaitu Kandawangan, Kotawaringin, Lawe, Sampit, dan Kapuas (Kalimantan Tengah), wilayah tengah yaitu Barito, Kandandangan, dan Tabalung (Kalimantan Selatan), wilayah timur yaitu Tanjung Kute, Pasir, Bumbu, dan Sawuku (Kalimantan Timur) (Pigeaud, 1960: 16-17). Dalam Kitab Negarakretagama sendiri tidak menyebutkan adanya Kerajaan Negara Dipa dan Negara Daha.

\section{Sisa Pemukiman Kuno di Tepian Sungai Negara Berdasarkan Data Arkeologis}

Penelitian arkeologi pada 2007 (Sunarningsih 2007) telah membuka dua kotak ekskavasi di Desa Penggandingan, Kecamatan Daha Utara (Tabel 1 dan 2). Kedua kotak ekskavasi tidak dapat diselesaikan karena faktor alam, yaitu mengalirnya air ke dalam kotak ekskavasi yang mengganggu dalam pengamatan lapisan tanah dan keberadaan artefak (konteks temuan). Dari hasil ekskavasi didapatkan data arkeologis yang dominan, yaitu pecahan genteng. Selain itu, juga ditemukan artefak lainnya seperti keramik asing, terak besi, pecahan gerabah. Temuan 
lain yang didapatkan pada saat survei di wilayah Kecamatan Daha Utara dan Daha Barat. Temuan penduduk juga diinventarisasi dan dianalisis, baik yang didapatkan dari aktivitas yang disengaja (mendulang) maupun yang ditemukan secara tidak disengaja pada saat melakukan aktivitas di sekitar lingkungannya. Selanjutnya, masing-masing artefak akan diuraikan di bawah ini.

\section{Artefak dari Kayu Ulin}

Peralatan dari kayu yang masih bisa bertahan meskipun sudah terendam selama ratusan tahun tentunya terbuat dari jenis kayu yang sangat kuat. Artefak kayu yang ditemukan terdiri atas, tiang ulin, tugal (tabel 4), alat pembuat jaring (tabel 5), dayung (tabel 6), gasing (tabel 7), dan wadah kayu (tabel 8). Peralatan ini dipakai oleh masyarakat untuk memenuhi kebutuhan primer akan papan dan pangan, di samping kebutuhan tersier, yaitu mendapatkan hiburan dari permainan gasing. Tiang ulin yang ditemukan dalam keaadaan masih tertanam dalam tanah dengan bagian ujung yang runcing serta bagian atas yang terbakar, menunjukkan bahwa masyarakat menggunakan jenis rumah bertiang sebagai tempat tinggalnya. Lingkaran tiang ulin yang besar dan panjang mengindikasikan tersedianya kayu ulin yang melimpah pada masa itu. Dengan ukuran tiang tersebut dapat diperkirakan bahwa bangunan yang berdiri merupakan bangunan yang besar juga. Meskipun demikian, belum dapat diperkirakan bentuk bangunannya, apakah merupakan bangunan tempat tinggal yang dipakai secara komunal (bangunan rumah panjang), yang biasa dipakai oleh masyarakat Dayak ataukah merupakan rumah tunggal. Denah rumah tersebut tentunya dapat diperkirakan apabila keberadaan tiangtiang yang masih tersisa bisa diukur jarak antartiang dan diketahui jumlah tiang yang berkelompok apakah membentuk denah tertentu.

Bentuk tiang yang bulat dengan ujung bagian bawah yang runcing serta adanya lubang yang tembus sebagai tempat kayu lain menunjukkan bahwa peralatan besi kemungkinan sudah mereka kenal. Oleh karena sifat dari kayu ulin yang sangat keras sehingga untuk dapat membentuk lubang yang berbentuk persegi diperlukan alat yang kuat. Meskipun demikian, tampaknya penggunaan paku dalam konstruksi rumah yang bertiang kayu ulin ini mungkin belum digunakan, masih dipakai sistem nat untuk menyatukan satu kayu dengan lainnya. Konstruksi rumah panggung menjadi pilihan yang tepat bagi masyarakat yang telah memiliki teknologi dalam pemanfaatan kayu ulin atau yang biasa disebut sebagai kayu besi. Lingkungan yang basah karena banyaknya daerah rawa dan aliran sungai di lereng Pegunungan
Meratus juga memberi pengaruh terhadap perkembangan jenis konstruksi bangunan di wilayah ini.

Peralatan kayu yang digunakan sebagai alat untuk memenuhi kebutuhan pangan antara lain adalah dayung, tugal, alat pembuat jaring, dan wadah kayu. Masih dengan bahan dari kayu ulin, tampaknya masyarakat pada masa itu banyak membuat peralatan dari kayu ulin karena memang bahan kayu tersebut melimpah dan bersifat lebih tahan terhadap air dan iklim panas/hujan. Ketrampilan yang sudah dikuasai dan peralatan yang mendukung tentunya sangat menentukan dalam proses pembentukan peralatan tersebut. Dayung yang digunakan sebagai alat untuk menggerakkan perahu (pada masa itu mesin tentunya belum dikenal) sangat penting guna mendukung kegiatan masyarakat sehari-hari, baik dalam hal bertansportasi maupun saat kegiatan mencari ikan. Ukuran dan bentuk dayung yang beragam tentunya juga memiliki maksud tertentu (foto1). Ukuran dan bentuk dayung dibuat dengan menyesuaikan ukuran perahu yang akan didayungnya. Perahu kecil akan membutuhkan ukuran dayung yang berbeda dengan perahu yang lebih besar. Terlihat dengan jelas bahwa masyarakat pada masa itu sudah menggunakan perahu beserta dayungnya secara intensif untuk mendukung kegiatan mereka sehari-hari, yaitu untuk sarana transportasi untuk mencapai satu tempat ke tempat lain (mengunjungi pusat perdagangan/pasar, ladang, tempat pemujaan, dan berkunjung ke saudara), untuk mencari ikan, untuk mengangkut barang (hasil pertanian, barang perdagangan), dan aktivitas lain yang memang dibutuhkan sekali. Lingkungan yang berair sangat membutuhkan perahu untuk dapat bertahan hidup.

Tugal atau disebut juga tutujah/tatanjuk yang juga dibuat dari kayu ulin digunakan oleh masyarakat untuk mendukung kegiatan pertanian. Temuan tugal dengan jumlah yang banyak dan bentuk yang bervariasi memberi petunjuk bahwa masyarakat pada masa itu telah menguasai teknologi pertanian. Tugal sendiri dipakai untuk membuat lubang di tanah yang akan ditaburi benih dari biji-bijian (foto 2). Tugal yang ditemukan semuanya polos tanpa pola hiasan. Hal tersebut mengindikasikan bahwa tugal tersebut digunakan pada kegiatan pertanian masyarakat, dan tidak digunakan sebagai suatu alat yang mempunyai nilai sakral, seperti halnya pada tatanjuk wayang. Apa saja jenis tanaman pertanian yang sudah mereka domestikasi masih memerlukan penelitian lebih lanjut. Mencari ikan dengan jaring tampaknya juga sudah dikenal, yang ditunjukkan dengan adanya alat pembuat jaring. 
Cobek atau alat untuk menggiling/ menghancurkan berbagai macam biji-bijian dan bahan lain (bumbu dapur) juga sudah menjadi kebutuhan bagi masyarakat pada masa itu guna mengolah bahan makanan sehari-hari. Wadah kayu yang lain seperti mangkuk yang menyerupai bentuk perahu dan wadah bentuk menyerupai ember juga digunakan oleh masyarakat dalam keseharian mereka. Sebenarnya tidak hanya wadah kayu saja yang digunakan oleh penduduk, tetapi juga wadah dari gerabah dan keramik asing juga dikenal.

Bentuk artefak dari kayu yang terakhir adalah gasing yang mempunyai bentuk seperti jantung dengan ukuran yang bervariasi (foto 3). Keberadaan gasing mengindikasikan bahwa masyarakat sudah mengenal permainan tersebut dan menjadi kebutuhan untuk mendapatkan hiburan di sela kegiatan yang mereka

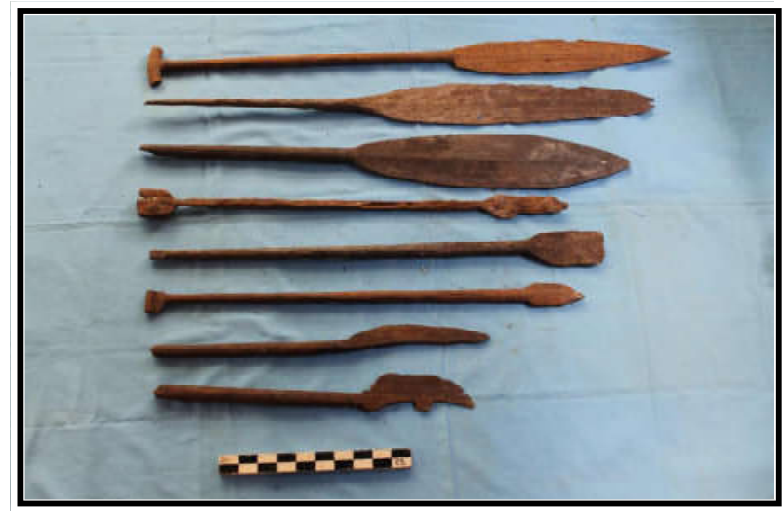

Foto 1. Temuan dayung dengan berbagai variasi bentuk dan ukuran (dok. Balai Arkeologi Banjarmasin).

lakukan untuk dapat bertahan hidup. Permainan gasing sangat dikenal oleh masyarakat dari berbagai pulau di Indonesia. Gasing sampai dengan saat ini masih menjadi salah satu permainan tradisional yang dipertahankan oleh berbagai suku di Indonesia, bahkan ada sebuah perkumpulan khusus yang dibentuk agar komunitas pecinta gasing tetap hidup di tengah gempuran beragai macam permainan modern pada masa sekarang. Ada tiga macam gasing yang memiliki cara permainan yang berbeda, yaitu gasing adu suara, gasing adu putar, dan gasing adu pukul/ kekuatan/pangkak. Untuk wilayah Kalimantan sendiri, permainan gasing disebut dengan "berpangkak". Bentuk gasing adu putar adalah berkepala dan berpasak (bagian bawah) kecil, sedangkan gasing adu pukul yang antara lain adalah berbentuk jantung tidak bisa lama berputar.

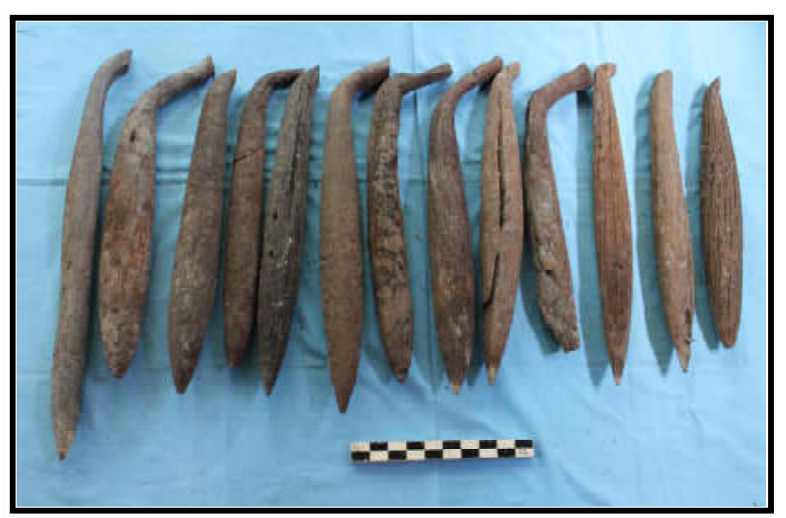

Foto 2. Temuan tugal (dok. Balai Arkeologi Banjarmasin).

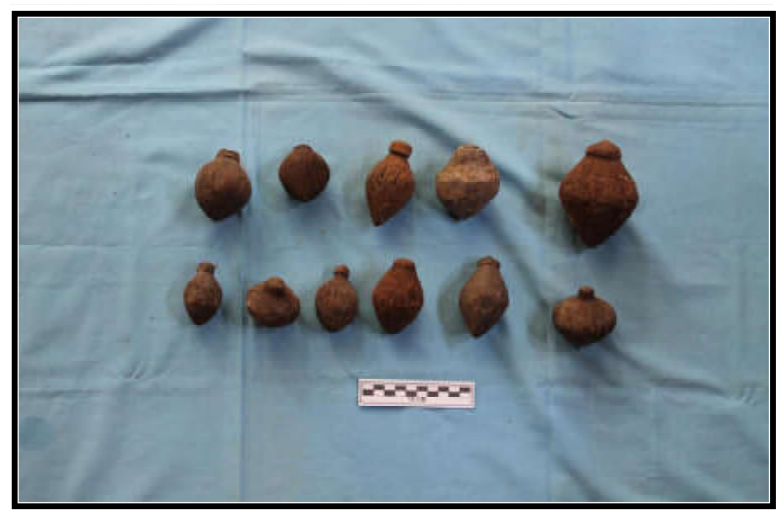

Foto 3. Temuan gasing bentuk jantung (dok. Balai Arkeologi Banjarmasin).

\section{Artefak dari Logam}

Artefak logam yang ditemukan seluruhnya berupa perhiasan (tabel 9). Perhiasan tersebut terbuat dari logam mulia, yaitu emas dan logam lainnya yaitu timah. Perhiasan emas (foto 4) tersebut bukan dari emas murni tetapi merupakan emas campuran yang kemungkinan besar adalah 18 karat. Bentuk perhiasan tersebut didominasi oleh cincin dengan beragam bentuk. Selain itu, ada sebuah manik emas dengan bentuk piramida ganda (akan dibahas dalam sub bab manik-manik). Ada beberapa bentuk perhiasan emas yang menarik yang tampaknya tidak hanya menjadi benda perhiasan tetapi menjadi simbol tertentu yang dapat memberi informasi terhadap kepercayaan masyarakat kuna di wilayah tersebut

Lempengan emas yang dilipat membentuk bujursangkar dilengkapi dengan ukiran geometris pada lempengan bagian luar adalah sebuah benda yang sangat penting bagi kehidupan masyarakat pada masa itu. Pada masa lalu, benda ini dipakai sebagai benda yang penting pada saat pembangunan tempat pemujaan dan juga rumah tinggal, yaitu berfungsi sebagai penolak bala. 


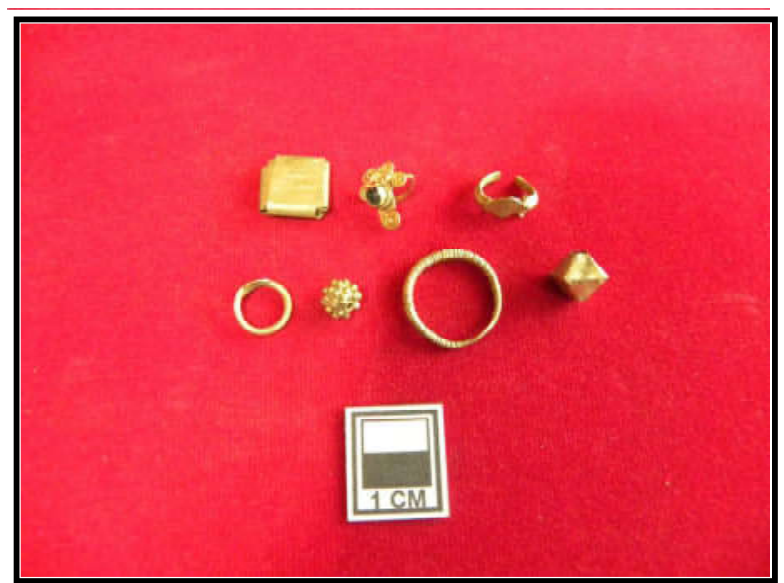

Foto 4. Berbagai bentuk perhiasan emas (dok. Balai Arkeologi Banjarmasin).

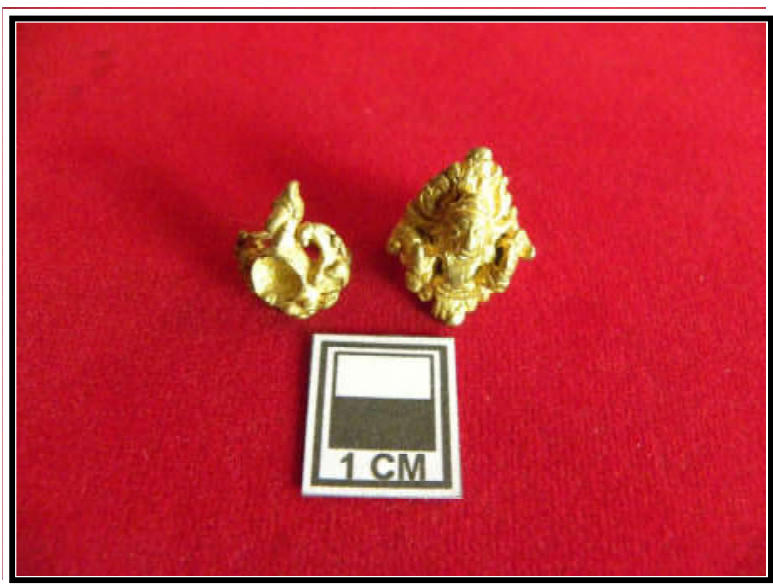

Foto 5. Berbagai bentuk artefak emas (dok. Balai Arkeologi Banjarmasin).

Demikian juga dengan perhiasan lain yang dilengkapi dengan gambar seorang laki-laki dengan memakai mahkota dan kedua tangannya memegang dua buah benda yang berbeda. Gambaran pada perhiasan tersebut menunjukkan ciri-ciri seorang dewa yang dipuja oleh kaum Hindu, yaitu Dewa Ciwa. Perhiasan yang lain berbentuk seekor burung garuda yang juga merupakan tunggangan salah satu dewa dalam agama Hindu. Kedua perhiasan tersebut menjadi petunjuk penting terhadap kepercayaan masyarakat kuna pada wilayah tersebut.

Keberadaan berbagai perhiasan logam di daerah pemukiman, selain menjadi petunjuk akan kepercayaan yang dimiliki oleh masyarakatnya, juga bisa menggambarkan bahwa masyarakat pada masa itu sudah mencapai sebuah kehidupan yang kompleks dan makmur. Masyarakat yang sudah terpenuhi kebutuhan akan sandang, pangan, dan papan, tentunya bisa membeli benda lain yang dibutuhkan untuk keperluan kehidupan sosial mereka, seperti kepercayaan, upacara, dan identitas dalam sebuah komunitas (status sosial).

\section{Manik-manik}

Manik adalah benda kecil yang berlubang di bagian tengahnya, sebagai tempat untuk merangkainya menjadi sebuah perhiasan, yaitu kalung atau gelang. Manik ternyata sudah mulai dikenal sejak jaman prasejarah dan mendapatkan tempat yang penting dalam kehidupan masyarakat karena selain berfungsi sebagai perhiasan juga digunakan sebagai penolak bala (Adhyatman dan Redjeki Arifin 1993, 1-2). Manikmanik yang ditemukan di situs pemukiman ini, dibuat dari berbagai macam bahan yang berbeda, yaitu batu, logam (emas), dan kaca (tabel 10).

Manik yang terbuat dari batu adalah manik kornelian dengan berbagai macam bentuk, yaitu bulat dempak, elips, kerucut ganda bersegi enam, dan cakram. Warna manik kornelian adalah antara coklat, merah, dan putih. Selain kornelian, juga ditemukan manik batuan hablur yang berwarna putih, dengan bentuk antara lain bulat dempak dan kerucut ganda segi enam. Pembuatan manik batu relatif lebih sulit dibandingkan dengan manik kaca. Oleh karena itu, jumlah temuan manik dari batu relatif lebih sedikit. Manik batu yang paling tua masuk ke Asia Tenggara memiliki bentuk bulat dempak sederhana dan bentuk tong, baru kemudian muncul (pada masa seribu tahun pertama) bentuk bersegi-segi dan kerucut ganda (ibid, 17). Bentuk terakhir menjadi lebih populer pada abad ke-12 M. Manik kornelian sendiri lebih banyak dihubungkan dengan kekuatan magis (ibid, 21-22).

Manik dari kaca yang ditemukan juga mempunyai beragam warna dan bentuk (foto 5). Manik kaca emas berasal dari Mesir (Asia Barat), yang kemungkinan berasal dari 300 M - 1000 M (Ibid., 29). Manik kaca yang berwarna kuning, biru tua, biru muda, coklat dan merah coklat (jingga), termasuk dalam jenis manik monokrom Indo-Pasifik. Istilah manik Indo-Pasifik diperkenalkan oleh Dr. Peter Francis berdasarkan daerah peredaran, warna, dan bahannya (Ibid, 15). Manik Indo-Pasifik sendiri masa dan tempat pembuatannya berbeda-beda. Tempat pembuatan manik tersebut antara lain (Ibid, 14-17) adalah Arikamedu (sekitar 250 SM - 250 M); Mantai, Sri Langka (abad ke-1 - 10); Klong Thom, Thailand Selatan (abad ke-2-6); Oc-eo, Vietnam yang merupakan Bandar Kerajaan Funan (abad ke-2 - 7); Palembang (Sumatera), Sating Phra (Thailand), dan Kuala Selinsing, Malaysia (abad ke-17). Manik tarik bergaris (hitam garis merah) juga termasuk dalam manik IndoPasifik. Oleh karena, masa produksi manik Indo-Pasifik yang sangat panjang, sulit untuk menggunakan manik ini sebagai alat menentukan pertanggalan relatif. Penentuan kronologi harus dipertimbangkan dengan 
konteks temuan dengan artefak lainnya, misalnya keramik China.

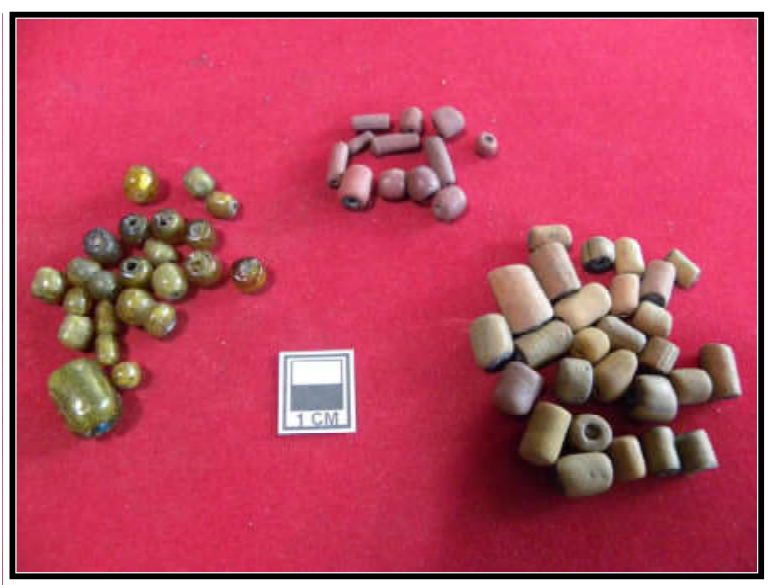

Foto 6. Manik-manik kaca (dok. Balai Arkeologi Banjarmasin).

\section{Gerabah dan Keramik}

Gerabah yang ditemukan dari hasil ekskavasi pada 2007 menunjukkan adanya dua jenis gerabah yang berbeda, yaitu gerabah wadah dan bukan wadah. Gerabah wadah memiliki bentuk periuk dan mangkuk, dengan didominasi oleh gerabah polos (tanpa hiasan). Gerabah bukan wadah antara lain adalah genteng dan batubata. Fragmen genteng merupakan jenis temuan yang terbanyak. Keberadaan genteng di situs ini sangat menarik, karena selama ini baru ada temuan fragmen genteng di Situs Candi Agung (Kusmartono dan Harry Widianto 1997/1998). Genteng di Situs Candi Agung digunakan sebagai atap bangunan candi yang bagian dasarnya tersusun dari batubata. Tampaknya, pada masa lalu genteng dan batubata hanya digunakan pada bangunan khusus, yaitu bangunan pemujaan. Oleh karena itu, keberadaan genteng dan batubata di Situs Panggandingan memberi informasi yang penting, apakah memang ada bangunan sakral atau bangunan penting lainnya di tempat tersebut. Gerabah temuan penduduk berupa kendi (tabel 12) yang berjumlah dua buah. Kedua kendi tersebut berwarna putih kemerahan. Yang menarik adalah kendi yang memiliki cerat ganda (foto 6), berkaki kecil, dan mungkin berleher pendek kecil (bagian leher sudah hilang). Bentuk kendi semacam juga ditemukan di wilayah Jawa Timur, yang diperkirakan merupakan kendi gerabah putih tipe Thai yang berasal dari abad ke-10-14 M (Adhyatman 1983, 31 \& 35). Kendi ini bentuknya mirip dengan kendi porselain biru putih yang berasal dari Dinasti Yuan, abad ke-14 M (Ibid, 79).

Keramik asing yang ditemukan, baik pada saat ekskavasi (tabel 3) maupun temuan penduduk (tabel 11 dan 13) merupakan keramik bentuk wadah (piring, mangkuk, vas, buli-buli, botol, dan tempayan). Kebanyakan keramik yang ditemukan berasal dari China (Adhyatman 1990). Keramik yang tertua berasal dari masa Dinasti Song (abad ke-11-13M), sedangkan yang paling banyak berasal dari masa Dinasti Yuan (abad ke-13-14 M). Keramik China dari masa yang lebih muda, yaitu Dinasti Ming (abad ke-14-17 M) dan Dinasti Qing (abad ke-17-19 M). Selain keramik China, juga ditemukan keramik dari Eropa yang berupa mangkuk, piring, dan botol. Selain terbuat dari keramik, botol Eropa juga terbuat dari kaca.

Menurut Wolters, perdagangan antara India dan Indonesia terjadi sebelum perdagangan Indonesia dengan China (Wolters 1967). Perdagangan dengan China baru dimulai pada sekitar abad ke 5 Masehi, yaitu pada saat Kerajaan Sriwijaya berkuasa. Pada masa itu, Kerajaan Sriwijaya sudah menguasai navigasi

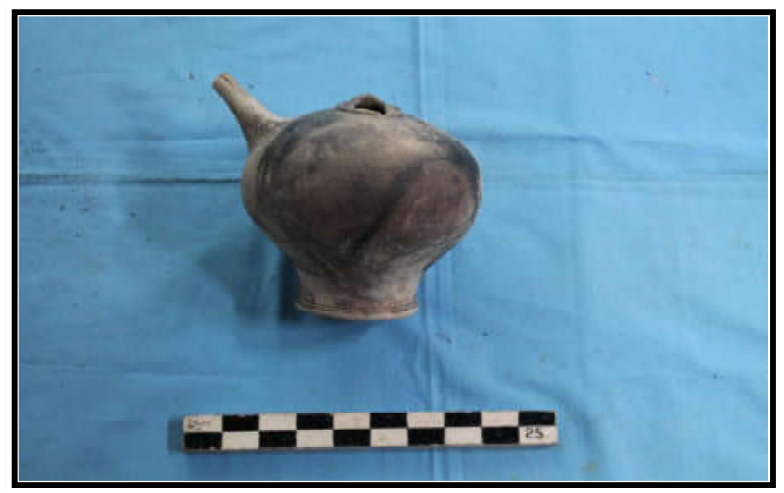

Foto 7. Kendi gerabah putih bercerat ganda (dok. Balai Arkeologi Banjarmasin).

dengan baik, sehingga dapat diperkirakan bahwa keramik China dibawa oleh pedagang Indonesia dengan menukar hasil hutan dan pertanian (Adhyatman 1990, 34).

Keramik bisa menjadi salah satu alat untuk menentukan pertanggalan relatif sebuah situs, karena pembuatan keramik pada masing-masing dinasti di China berbeda-beda. Berdasarkan hasil temuan keramik China di Negara yang didominasi oleh keramik Yuan, dapat diperkirakan bahwa keramik tersebut di perdagangkan ke wilayah Kalimantan pada sekitar abad ke-14 Masehi. Meskipun demikian, tetap ada kemungkinan juga perdagangan dengan China sudah dimulai pada masa sebelumnya, dan masih tetap berlangsung pada masa yang lebih muda. Keramik China juga bisa digunakan sebagai simbol status sosial pemiliknya, karena harga barang ini tidaklah murah (pada masa itu). Kemungkinan besar situs sudah dihuni sejak abad ke-12- 13 Masehi didasarkan pada keberadaan manik-manik Indo-Pacifik dan kendi. 


\section{E. Letak Kerajaan Negara Daha di Wilayah Negara}

Hasil analisis dan sintesis data artefaktual di atas memberi gambaran bahwa kehidupan masyarakat yang bermukim di Negara pada masa lalu sudah sangat kompleks. Kebutuhan pangan terpenuhi dari aktivitas pertanian dengan menggunakan peralatan tugal sebagai alat untuk bercocok tanam. Kemungkinan besar domestikasi padi dan tanaman palawija lain yang menggunakan biji-bijian sebagai benihnya sudah dikenal, disamping tanaman jenis lain seperti umbi-umbian. Teknologi transportasi guna mendukung pengangkutan hasil pertanian dan alat transportasi juga sudah maju. Oleh karena kebutuhan pokok mereka sudah terjamin, maka kebutuhan lainnya seperti status sosial (perhiasan emas, manik-manik, keramik) dan hiburan (gasing) dapat dipenuhi. Keberadaan manik-manik dari luar dan juga keramik asing yang menjadi komoditas penting pada masa itu memperkuat indikasi adanya interaksi dengan dunia luar melalui aktivitas perdagangan. Lokasi tempat tinggal masyarakat yang jauh dari jalur perdagangan tidak menjadi sebuah kendala. Kemampuan untuk terlibat dalam aktivitas perdagangan juga bisa menjadi petunjuk bahwa masyarakat sudah memiliki berbagai macam pekerjaan. Perhiasan yang ditemukan memberi gambaran kepercayaan yang dianut oleh masyarakat sudah mendapat pengaruh agama Hindu.

Hal tersebut juga didukung oleh adalah temuan genteng dan batu bata di Situs Penggandingan yang mengindikasikan adanya sebuah bangunan penting (sakral), seperti halnya yang ditemukan di Candi Agung (abad ke-8 M) dan Candi Laras (abad ke-14 M) ((Kusmartono dan Widianto 1997/1998; Sulistyanto 2000). Berdasarkan keletakannya, Negara berada di antara Candi Agung (ke arah hulu) dan Candi Laras (ke arah hilir)(Peta 1), keduanya sangat penting sebagai bukti adanya kegiatan pemujaan dalam agama Hindu.

Meskipun data arkeologi di Situs Penggandingan masih terbatas (temuan genteng dan batubata), cukup menjadi bukti bahwa lokasi tersebut juga memegang peranan penting. Banyaknya temuan keramik asing, pemukiman kuna di sekitarnya, dan toponim Negara dan Daha memperkuat asumsi bahwa Negara Daha dulunya memang berpusat di wilayah Tumbukan Banyu tersebut. Selain itu, keberadaan masyarakat Negara pada saat ini yang sangat unik, yaitu masih menekuni pekerjaan pokoknya sebagai pengrajin baik gerabah (Sulistyanto dan Indah Asikin Nurani 1999/ 2000) maupun logam dan menjadi satu-satunya pusat berkumpulnya para pengrajin memberikan informasi yang cukup signifikan adanya kontinuitas aktivitas serupa pada masa lalu.

Meskipun demikian, keberadaan pemukiman kuna yang berada di wilayah Negara tampaknya masih belum bisa menjawab pertanyaan yang terkait dengan luas wilayah kekuasaan Kerajaan Negara Daha, baik itu daerah intinya (core) di mana kraton dan lingkungannya atau pusat pemerintahan berada maupun daerah penyangganya (periphery).

\section{F. Penutup}

Meskipun data yang didapatkan sementara ini masih jauh dari yang diharapkan, tetapi keberadaan data arkeologis di Negara dan sekitarnya dapat memberi gambaran bahwa pada masa lalu tempat tersebut sudah memegang peranan penting sebagai bagian dari wilayah Negara Daha. Berdasarkan data arkeologi dapat diasumsikan bahwa di Penggandingan ada indikasi bangunan sakral dan atau bangunan lain yang digunakan pada masa pemerintahan Negara Daha.

Untuk dapat memperkuat asumsi bahwa Kerajaan Daha berlokasi di tempat tersebut, perlu dilakukan ekskavasi lanjutan, terutama di Situs Penggandingan guna merekonstruksi kembali fungsi dari temuan fragmen genteng dan batubata di tempat tersebut. Selain itu, perlu juga dilakukan survei yang lebih mendalam terhadap sebaran pemukiman di sepanjang Sungai Negara, baik ke arah hulu maupun hilir. Penelitian yang dilakukan harus disertai dengan analisis pertanggalan secara absolut, menggunakan artefak yang mengandung unsur karbon (sampel kayu dan arang), sehingga kronologi masing-masing situs menjadi jelas. Hasil penelitian tersebut diharapkan dapat menambah informasi yang diperlukan dalam penyusunan sejarah Kerajaan Negara Daha di Kalimantan Selatan. 


\section{Referensi}

Adhyatman, Sumarah. 1983. Kendi. Jakarta: Himpunan Keramik Indonesia.

1990. Antique ceramics found in Indonesia. Jakarta: Ceramic society of Indonesia

Adhyatman, Sumarah dan Redjeki Arifin. 1993. Manikmanik di Indonesia. Jakarta: Djambatan.

Harkantiningsih, Naniek dkk. 1999. Metode Penelitian Arkeologi. Jakarta: Pusat Penelitian Arkeologi Nasional.

Ideham, M. Suriansyah dkk. 2007. Urang Banjar dan Kebudayaannya. Banjarmasin: Badan Pengembangan dan Penelitian Daerah Propinsi Kalimantan Selatan.

Kusmartono, Vida Pervaya Rusianti dan Harry Widianto. 1997/1998. Ekskavasi Situs Candi Agung Kabupaten Hulu Sungai Utara Kalimantan Selatan. Berita Penelitian Arkeologi No. 2. Banjarmasin: Balai Arkeologi.

Poesponegoro, Marwati Djoened dan Nugroho Notosusanto. 1993. Sejarah Nasional Indonesia II. Jakarta: Balai Pustaka.

Piegaud, TH. 1960. Java in The Fourtheenth Century. The Hague: Martinus Nijhoff .

Saleh, Idwar dkk. 1997/1978. Sejarah daerah Kalimantan Selatan. Jakarta: Proyek penelitian dan pencatatan kebudayaan daerah.

Soejono, R. P. 1981. Tinjauan tentang perkerangkaan Prasejarah Indonesia, Aspek-aspek Arkeologi Indonesia (Aspects of Indonesian Archaeology) No. 5. Jakarta: Pusat Penelitian Arkeologi Nasional.

Sulistyanto, Bambang. 2000. Umur Candi Laras dalam Panggung Sejarah Indonesia Kuna, Berita Penelitian Arkeologi No. 7. Banjarbaru: Balai Arkeologi Banjarmasin.
Sulistyanto, Bambang dan Indah Asikin Nurani. "Penelitian Etnoarkeologi Tradisi Pembuatan Gerabah Nagara, Hulu Sungai Selatan, Kalimantan Selatan". Berita Penelitian Arkeologi No. 5. Balai Arkeologi Banjarmasin. 1999/2000.

Sunarningsih. 2007. Penelitian ekskavasi permukiman di Nagara, Kabupaten Hulu Sungai Selatan, Kalimantan Selatan, Laporan Penelitian Arkeologi, Balai Arkeologi Banjarmasin. Belum terbit.

2012. "Sebaran situs pemukiman kuna di Daerah Aliran Sungai Barito" dalam Naditira Widya 6 (2): 130 - 144.

Rass, J. J. Hikayat Banjar. Tranlated by Siti Hawa Salleh. Kuala Lumpur: Dewan Bahasa dan Pustaka. 1990

Renfrew, Colin dan Paul Bahn. 2006. Archaeology the key concept. Oxon: Routledge. 2008. Chapter 9 "Trade and Change", in Archaeology Theories, Methodes, Practice. Thames \& Hudson, 357-390.

Wolter, O. W. 1967. Early Indonesian Commerce: A Study of the Origins of Srivijaya. Cornell University Press. Ithaca, New York.

Kulke, Hermann. 1990. The early and the imperial kingdom in Southeast Asian history dalam Southeast Asia in the $9^{\text {th }}$ to $14^{\text {th }}$ centuries, (eds) David G. Marr and A.c. Milner. Singapore: Institute of Southeast Asian Studies, 1-22. books.google.co.id., diunduh 3 Juli 2013.

1991. Epigraphical refernces to the city and the state in early Indonesia, dalam Indonesia No. 52 (Oct ,1991), 3-22. Southeast Asia Program at Cornell University. Http:/ www.jstor.org/stable/3351152, diunduh 2 Juli 2013. 


\section{Lampiran}

Tabel 1. Temuan di Kotak TP 1 Situs Penggandingan

\begin{tabular}{|c|l|l|l|}
\hline No & \multicolumn{1}{|c|}{ Layer } & \multicolumn{1}{|c|}{ Temuan } & \multicolumn{1}{c|}{ Keterangan } \\
\hline 1 & $\begin{array}{l}\text { (spit 1-2 pada kedalaman 0- } \\
30 \mathrm{~cm})\end{array}$ & $\begin{array}{l}\text { Fragmen genteng, fragmen gerabah wadah (tepian, } \\
\text { dasar, badan polos/berhias, tutup), fragmen kendi, } \\
\text { fragmen tungku, manik-manik, fragmen besi, fragmen } \\
\text { keramik asing, terak besi }\end{array}$ & $\begin{array}{l}\text { Yang paling dominan adalah } \\
\text { fragmen genteng }\end{array}$ \\
\hline 2 & $\begin{array}{l}2 \\
(\text { spit 3-4 pada kedalaman } \\
30-50 \mathrm{~cm})\end{array}$ & $\begin{array}{l}\text { Fragmen genteng, fragmen gerabah wadah (tepian, } \\
\text { dasar, badan polos/berhias, tutup), fragmen kendi, } \\
\text { fragmen tungku, fragmen keramik asing, terak besi }\end{array}$ & sda- \\
\hline 3 & $\begin{array}{l}3 \\
\text { (pada kedalaman 50-160 } \\
\mathrm{cm})\end{array}$ & $\begin{array}{l}\text { Fragmen genteng, fragmen gerabah wadah (tepian, } \\
\text { dasar, badan polos/berhias, tutup), fragmen kendi, } \\
\text { fragmen tungku, manik-manik, fragmen besi, fragmen } \\
\text { bata, fragmen keramik asing, terak besi, damar }\end{array}$ & $\begin{array}{l}\text { Masih didominasi oleh temuan } \\
\text { fragmen genteng. Layer ke-3 ini } \\
\text { mulai dimasuki oleh air dengan } \\
\text { sumber yang sangat deras, } \\
\text { aktivitas penggalian hanya } \\
\text { menggunakan sundak dengan } \\
\text { ukuran panjang } 10 \mathrm{~cm} . \text { Jadi, } \\
\text { setelah kedalaman } 50 \mathrm{~cm} \text { jumlah } \\
\text { layer tidak dapat lihat. }\end{array}$ \\
\hline
\end{tabular}

Tabel 2. Temuan di Kotak TP 2 Situs Penggandingan

\begin{tabular}{|c|c|c|c|}
\hline No & Layer & Temuan & Keterangan \\
\hline 1 & $\begin{array}{l}1 \\
\text { (spit } 1 \text { pada kedalaman } 0- \\
20 \mathrm{~cm})\end{array}$ & $\begin{array}{l}\text { Fragmen gerabah, fragmen keramik asing, terak besi, } \\
\text { sampah plastik }\end{array}$ & merupakan tanah urug \\
\hline 2 & $\begin{array}{l}2 \\
\text { (spit 2-3 pada kedalaman } \\
20-40 \mathrm{~cm})\end{array}$ & $\begin{array}{l}\text { Fragmen gerabah wadah, fragmen kendi, fragmen } \\
\text { genteng, terak besi, fragmen keramik asing }\end{array}$ & $\begin{array}{l}\text { Merupakan tanah lempung } \\
\text { pasiran warna ababu } \\
\text { kecoklatan }\end{array}$ \\
\hline 3 & $\begin{array}{l}3 \\
\text { (spit } 4 \text { pada kedalaman } 40- \\
50 \mathrm{~cm} \text { ) }\end{array}$ & $\begin{array}{l}\text { Fragmen gerabah wadah, fragmen bata, fragmen } \\
\text { genteng, fragmen keramik asing }\end{array}$ & $\begin{array}{l}\text { Warna tanah hitam keabu-abuan } \\
\text { dengan banyak unsur hara dan } \\
\text { kandungan air }\end{array}$ \\
\hline 4 & $\begin{array}{l}4 \\
\text { (spit } 5-7 \text { pada kedalaman } \\
50-80 \mathrm{~cm} \text { ) }\end{array}$ & $\begin{array}{l}\text { Fragmen gerabah wadah, fragmen keramik asing, terak } \\
\text { besi, fragmen genteng, fragmen kendi, fragmen kayu }\end{array}$ & $\begin{array}{l}\text { Warna tanah hitam keabu-abuan } \\
\text { dengan banyak unsur hara dan } \\
\text { kandungan air }\end{array}$ \\
\hline 5 & $\begin{array}{l}5 \\
\text { (spit } 8 \text { pada kedalaman } \\
90 \mathrm{~cm})\end{array}$ & $\begin{array}{l}\text { Fragmen gerabah wadah (tepian, badan polos/berhias, } \\
\text { dasar), fragmen kendi, fragmen genteng, fragmen } \\
\text { keramik asing, fragmen kayu, terak besi }\end{array}$ & Warna tanah coklat keabu-abuan \\
\hline
\end{tabular}

Tabel 3. Temuan keramik asing dari TP1 dan TP 2, Situs Penggandingan

\begin{tabular}{|c|l|l|l|l|l|l|}
\hline No & \multicolumn{1}{|c|}{ Bahan } & \multicolumn{1}{c|}{ Bentuk } & \multicolumn{1}{c|}{ Warna Glasir } & Diameter $(\mathbf{c m})$ & \multicolumn{1}{c|}{ Pola Hias } & \multicolumn{1}{c|}{ Asal } \\
\hline 1 & Batuan/stoneware & tempayan & coklatkehitaman, tipis & - & naga & Ming \\
\hline 2 & Batuan & tempayan & hijau tua & - & - & Yuan \\
\hline 3 & Batuan & tempayan & coklathitam & - & - & Yuan \\
\hline 4 & Batuan & tempayan & - & - & geometris & Yuan \\
\hline 5 & Batuan & tempayan & hijau & 7 (ring base) & - & Yuan \\
\hline 6 & Batuan & tempayan & coklataus & $\begin{array}{l}12,18,22 \\
\text { (flat base })\end{array}$ & $\begin{array}{l}\text { kala (kedok) pada } \\
\text { pegangan }\end{array}$ & Ming \\
\hline
\end{tabular}




\begin{tabular}{|c|c|c|c|c|c|c|}
\hline No & Bahan & Bentuk & Warna Glasir & Diameter (cm) & Pola Hias & Asal \\
\hline 7 & Batuan & tempayan & hijau & - & \begin{tabular}{|l} 
geometris \\
(gelombang)
\end{tabular} & Yuan \\
\hline 8 & Batuan & guci & - & 13 (base) & - & Yuan \\
\hline 9 & Batuan & guci & coklat tipis & - & - & Yuan \\
\hline 10 & Batuan & guci & hijau & - & geometris & Yuan \\
\hline 11 & Batuan & botol & - & 6 (base) & - & Yuan \\
\hline 12 & Batuan & gentong & coklat tipis & $\begin{array}{l}34, \quad 30, \quad 20 \\
\text { (tepian terbuka) }\end{array}$ & - & Yuan \\
\hline 13 & Porselen & piring & seladon & 10 (tepian) & teratai & Yuan \\
\hline 14 & Porselen & piring & biru putih & - & geometris & Yuan \\
\hline 15 & Porselen & piring & putih, seladon & - & - & Yuan \\
\hline 16 & Porselen & piring & putih pecah seribu & - & geometris (emboss) & Eropa \\
\hline 17 & Porselen & piring & seladon kecoklatan & 16 (tepian) & lundang-lundang & Yuan \\
\hline 18 & Porselen & piring & putih keabuan & - & ikan (sgrafito) & Yuan Akhir \\
\hline 19 & Porselen & guci kecil & seladon & 2 (tepian) & ada pegangan & Yuan \\
\hline 20 & Porselen & guci & seladon & ring base & - & Yuan \\
\hline 21 & Porselen & buli-buli & hijau terang & - & - & Yuan \\
\hline 22 & Porselen & basi & putih & - & geometris (emboss) & Eropa \\
\hline 23 & Porselen & basi & putih pecah seribu & - & - & Eropa \\
\hline 24 & Porselen & mangkuk & seladon & - & - & Yuan \\
\hline 25 & Porselen & $\begin{array}{l}\text { mangkuk } \\
\text { bertutup }\end{array}$ & putih & - & geometris (emboss) & Eropa \\
\hline 26 & Porselen & mangkuk & hijau pecah seribu & 6,12 (dasar) & - & Yuan \\
\hline 27 & Porselen & mangkuk & putih & - & geometris (emboss) & Yuan \\
\hline 28 & Porselen & mangkuk & seladon kecoklatan & - & - & Eropa \\
\hline 29 & Porselen & mangkuk & putih & 16 (tepian) & - & Yuan \\
\hline 30 & Porselen & mangkuk & hijau & 7, 8 (ring base) & - & Yuan \\
\hline 31 & Porselen & mangkuk & putih pecah seribu & 5 (ring base) & - & Yuan \\
\hline 32 & Porselen & mangkuk & putih & - & - & Ming \\
\hline 33 & Porselen & cepuk & seladon & - & - & Yuan \\
\hline 34 & Porselen & cepuk & hijau pecah seribu & 6 (flat base) & - & Yuan \\
\hline 35 & Porselen & cepuk & putih hijau & ring base & - & Yuan \\
\hline 36 & Porselen & tutup cepuk & seladon & - & - & Yuan \\
\hline 37 & Porselen & mangkuk & seladon & - & lundang-lundang & Yuan \\
\hline 38 & Porselen & mangkuk & biru putih & - & geometris & Qing \\
\hline 39 & Porselen & mangkuk & seladon pecah seribu & - & - & Yuan \\
\hline 40 & Porselen & mangkuk & seladon kecoklatan & - & - & Yuan \\
\hline 41 & Batuan & tempayan & - & - & - & Yuan \\
\hline
\end{tabular}


Tabel 4. Tugal (alat pertanian)

\begin{tabular}{|c|c|c|c|c|c|c|}
\hline \multirow{2}{*}{ No } & \multirow{2}{*}{ Bentuk } & \multicolumn{3}{|c|}{ Ukuran (cm) } & \multirow{2}{*}{ Bahan/Fungsi } & \multirow{2}{*}{ Keterangan } \\
\hline & & \begin{tabular}{|c|} 
Panjang \\
Tugal
\end{tabular} & \begin{tabular}{|c|} 
Panjang \\
Pegangan
\end{tabular} & Diameter & & \\
\hline 1 & $\begin{array}{l}\text { Bulat lonjong, ujung bawah } \\
\text { runcing, ujung atas (bagian } \\
\text { pegangan) bengkok }\end{array}$ & 63 & 5 & - & $\begin{array}{l}\text { Kayu ulin, untuk membuat } \\
\text { lubang tempat benih } \\
\text { ditanam }\end{array}$ & $\begin{array}{l}\text { Kondisi permukaan tugal relatif } \\
\text { masih bagus }\end{array}$ \\
\hline 2 & $\begin{array}{l}\text { Bulat lonjong, bagian } \\
\text { tengah tebal dengan ujung } \\
\text { bawah runcing dan ujung } \\
\text { atas bengkok sebagai } \\
\text { pegangan }\end{array}$ & 54 & 10 & - & Sda & $\begin{array}{l}\text { Kondisi permukaan tugal sudah } \\
\text { mengalami perubahan terbentuk } \\
\text { lubang dan terkelupas sebagian } \\
\text { permukaan kayunya }\end{array}$ \\
\hline 3 & $\begin{array}{l}\text { Bulat lonjong, bagian ujung } \\
\text { bawah runcing dan bagian } \\
\text { pegangan sedikit } \\
\text { melengkung }\end{array}$ & 50 & 1 & - & Sda & Sda \\
\hline 4 & $\begin{array}{l}\text { Bulat lonjong, dengan } \\
\text { ujung bawah meruncing, } \\
\text { ujung atas melengkung }\end{array}$ & 49 & 5 & - & Sda & Sda \\
\hline 5 & $\begin{array}{l}\text { Bulat lonjong, dengan } \\
\text { ujung bawah meruncing, } \\
\text { ujung atas melengkung } \\
\text { sedikit }\end{array}$ & 52 & 1 & - & Sda & $\begin{array}{l}\text { Kondisi tugal sudah retak yang } \\
\text { membentuk lubang panjang di } \\
\text { bagian badan tugal }\end{array}$ \\
\hline 6 & $\begin{array}{l}\text { Bulat lonjong, dengan } \\
\text { ujung bawah meruncing, } \\
\text { ujung atas melengkung }\end{array}$ & 55 & 5,5 & - & Sda & $\begin{array}{l}\text { Kondisi permukaan tugal relatif } \\
\text { masih bagus }\end{array}$ \\
\hline 7 & $\begin{array}{l}\text { Bulat lonjong, dengan } \\
\text { ujung bawah meruncing, } \\
\text { ujung atas melengkung }\end{array}$ & 52 & 8 & - & Sda & $\begin{array}{l}\text { Kondisi permukaan tugal sudah } \\
\text { mengalami perubahan terbentuk } \\
\text { lubang dan terkelupas sebagian } \\
\text { permukaan kayunya }\end{array}$ \\
\hline 8 & $\begin{array}{l}\text { Bulat lonjong, dengan } \\
\text { ujung bawah meruncing, } \\
\text { ujung atas melengkung }\end{array}$ & 56 & 10 & - & Sda & Sda \\
\hline 9 & $\begin{array}{l}\text { Bulat lonjong, dengan } \\
\text { ujung bawah meruncing, } \\
\text { ujung atas melengkung } \\
\text { sedikit }\end{array}$ & 53 & 1 & - & Sda & $\begin{array}{l}\text { Kondisi tugal sudah retak yang } \\
\text { membentuk lubang panjang di } \\
\text { bagian badan tugal }\end{array}$ \\
\hline 10 & $\begin{array}{l}\text { Bulat lonjong, dengan } \\
\text { ujung bawah patah, ujung } \\
\text { atas melengkung }\end{array}$ & 46 & 9,5 & - & Sda & $\begin{array}{l}\text { Kondisi tugal sudah retak yang } \\
\text { membentuk lubang panjang di } \\
\text { bagian badan tugal }\end{array}$ \\
\hline 11 & $\begin{array}{l}\text { Bulat lonjong, dengan } \\
\text { ujung bawah meruncing, } \\
\text { ujung atas melengkung } \\
\text { sedikit }\end{array}$ & 54 & 2,5 & - & Sda & $\begin{array}{l}\text { Kondisi tugal sudah retak yang } \\
\text { membentuk lubang panjang di } \\
\text { bagian badan tugal }\end{array}$ \\
\hline 12 & $\begin{array}{l}\text { Bulat lonjong, dengan } \\
\text { ujung bawah meruncing, } \\
\text { ujung atas melengkung } \\
\text { sedikit }\end{array}$ & 51 & 1 & - & Sda & $\begin{array}{l}\text { Kondisi tugal sudah retak yang } \\
\text { membentuk lubang panjang di } \\
\text { bagian badan tugal }\end{array}$ \\
\hline 13 & $\begin{array}{l}\text { Bulat lonjong, dengan } \\
\text { ujung bawah meruncing, } \\
\text { ujung atas melengkung } \\
\text { sedikit }\end{array}$ & 46 & 1 & - & Sda & $\begin{array}{l}\text { Kondisi tugal sudah retak yang } \\
\text { membentuk lubang panjang di } \\
\text { bagian badan tugal }\end{array}$ \\
\hline
\end{tabular}




\begin{tabular}{|c|c|c|c|c|c|c|}
\hline \multirow{2}{*}{ No } & \multirow{2}{*}{ Bentuk } & \multicolumn{3}{|c|}{ Ukuran $(\mathrm{cm})$} & \multirow{2}{*}{ Bahan/Fungsi } & \multirow{2}{*}{ Keterangan } \\
\hline & & \begin{tabular}{|c|} 
Panjang \\
Tugal
\end{tabular} & \begin{tabular}{|c|} 
Panjang \\
Pegangan
\end{tabular} & Diameter & & \\
\hline 14 & $\begin{array}{l}\text { Bulat lonjong, dengan } \\
\text { ujung bawah meruncing, } \\
\text { ujung atas (bagian } \\
\text { pegangan) lurus }\end{array}$ & \begin{tabular}{|l|}
50 \\
\\
\end{tabular} & 7,5 & - & Sda & $\begin{array}{l}\text { Kondisi tugal sudah retak yang } \\
\text { membentuk lubang panjang di } \\
\text { bagian badan tugal }\end{array}$ \\
\hline 15 & $\begin{array}{l}\text { Bulat lonjong, dengan } \\
\text { ujung bawah meruncing, } \\
\text { ujung atas (bagian } \\
\text { pegangan) lurus }\end{array}$ & 40 & 7 & - & Sda & $\begin{array}{l}\text { Kondisi tugal sudah retak yang } \\
\text { membentuk lubang panjang di } \\
\text { bagian badan tugal }\end{array}$ \\
\hline 16 & $\begin{array}{l}\text { Bulat lonjong, dengan } \\
\text { ujung bawah meruncing, } \\
\text { ujung atas (bagian } \\
\text { pegangan)lurus }\end{array}$ & 35 & 7 & - & Sda & $\begin{array}{l}\text { Kondisi tugal sudah retak yang } \\
\text { membentuk lubang panjang di } \\
\text { bagian badan tugal }\end{array}$ \\
\hline 17 & $\begin{array}{l}\text { Bulat lonjong, dengan } \\
\text { ujung bawah meruncing, } \\
\text { ujung atas (bagian } \\
\text { pegangan) lurus }\end{array}$ & 35 & 8 & - & Sda & $\begin{array}{l}\text { Kondisi permukaan tugal sudah } \\
\text { mengalami perubahan terbentuk } \\
\text { lubang dan terkelupas sebagian } \\
\text { permukaan kayunya }\end{array}$ \\
\hline 18 & $\begin{array}{l}\text { Bulat lonjong, dengan } \\
\text { ujung bawah meruncing, } \\
\text { ujung atas (bagian } \\
\text { pegangan) lurus }\end{array}$ & 35 & 8 & - & Sda & $\begin{array}{l}\text { Kondisi permukaan tugal sudah } \\
\text { mengalami perubahan terbentuk } \\
\text { lubang dan terkelupas sebagian } \\
\text { permukaan kayunya }\end{array}$ \\
\hline 19 & $\begin{array}{l}\text { Bulat lonjong, dengan } \\
\text { ujung bawah meruncing, } \\
\text { ujung atas (bagian } \\
\text { pegangan) lurus }\end{array}$ & 30 & 7 & - & Sda & $\begin{array}{l}\text { Kondisi permukaan tugal sudah } \\
\text { mengalami perubahan terbentuk } \\
\text { lubang dan terkelupas sebagian } \\
\text { permukaan kayunya }\end{array}$ \\
\hline 20 & $\begin{array}{l}\text { Bulat lonjong, dengan } \\
\text { ujung bawah meruncing, } \\
\text { ujung atas (bagian } \\
\text { pegangan)lurus }\end{array}$ & 27 & 10 & - & Sda & $\begin{array}{l}\text { Kondisi permukaan tugal sudah } \\
\text { mengalami perubahan terbentuk } \\
\text { lubang dan terkelupas sebagian } \\
\text { permukaan kayunya }\end{array}$ \\
\hline
\end{tabular}

Tabel 5. Alat pembuat jaring (?)

\begin{tabular}{|l|l|l|l|l|l|l|}
\hline No & \multicolumn{2}{|c|}{ Bentuk } & \multicolumn{2}{c|}{ Ukuran (cm) } & \multirow{2}{*}{ Bahan/Fungsi } & Keterangan \\
\cline { 2 - 6 } & Panjang & $\begin{array}{l}\text { Panjang } \\
\text { Pegangan }\end{array}$ & Diameter & $\begin{array}{l}\text { Kayu ulin, untuk membuat } \\
\text { ujung garpu hanya dua } \\
\text { buah }\end{array}$ & $7, ?)$ & warna coklat \\
\hline 2 & $\begin{array}{l}\text { Menyerupai garpu, tetapi } \\
\text { ujung garpu hanya dua } \\
\text { buah }\end{array}$ & 12 & 4 & - & Sda & warna coklat tua \\
\hline
\end{tabular}

Tabel 6. Dayung

\begin{tabular}{|l|l|l|l|l|l|l|}
\hline \multirow{2}{*}{ No } & \multirow{2}{*}{ Bentuk } & \multicolumn{3}{c|}{ Ukuran (cm) } & \multirow{2}{*}{ Bahan/Fungsi } & Keterangan \\
\cline { 3 - 7 } & Panjang & $\begin{array}{l}\text { Panjang } \\
\text { Pegangan }\end{array}$ & Diameter & & \\
\hline 1 & Dayung & 43 & - & - & $\begin{array}{l}\text { Kayu ulin, untuk } \\
\text { menggerakkan perahu }\end{array}$ & $\begin{array}{l}\text { Bagian dayung yang lebar dan } \\
\text { pipih hanya tinggal sebagian kecil } \\
\text { saja }\end{array}$ \\
\hline 2 & Dayung & 47 & - & - & Sda & Sda \\
\hline
\end{tabular}




\begin{tabular}{|c|c|c|c|c|c|c|}
\hline \multirow[b]{2}{*}{ No } & \multirow{2}{*}{ Bentuk } & \multicolumn{3}{|c|}{ Ukuran (cm) } & \multirow{2}{*}{ Bahan/Fungsi } & \multirow{2}{*}{ Keterangan } \\
\hline & & $\begin{array}{l}\text { Panjang } \\
\text { Tugal }\end{array}$ & \begin{tabular}{|l|} 
Panjang \\
Pegangan
\end{tabular} & Diameter & & \\
\hline 3 & Dayung & 64 & - & - & Sda & $\begin{array}{l}\text { Bagian dayung yang lebar dan } \\
\text { pipih hanya tinggal sebagian kecil } \\
\text { saja, bagian ujung pegangan } \\
\text { sedikit melebar }\end{array}$ \\
\hline 4 & Dayung & 62 & - & - & Sda & Sda \\
\hline 5 & Dayung & 66 & - & - & Sda & $\begin{array}{l}\text { Bagian dayung yang lebar dan } \\
\text { pipih hanya tinggal sebagian kecil } \\
\text { saja }\end{array}$ \\
\hline 6 & Dayung & 74 & - & - & Sda & $\begin{array}{l}\text { Bagian dayung yang lebar dan } \\
\text { pipih masih utuh }\end{array}$ \\
\hline 7 & Dayung & 80 & - & - & Sda & Sda \\
\hline 8 & Dayung & 85 & - & - & Sda & $\begin{array}{l}\text { Bagian dayung yang lebar dan } \\
\text { pipih masih utuh,bagian ujung } \\
\text { pegangan sedikit melebar }\end{array}$ \\
\hline 9 & Dayung & 129 & - & - & Sda & $\begin{array}{l}\text { Bagian dayung yang lebar dan } \\
\text { pipih masih utuh, bagian ujung } \\
\text { pegangan lebih tebal }\end{array}$ \\
\hline 10 & Dayung & 129 & - & - & Sda & Sda \\
\hline 11 & Dayung & 144 & - & - & Sda & $\begin{array}{l}\text { Bagian dayung yang lebar dan } \\
\text { pipih masih utuh,bagian ujung } \\
\text { pegangan sedikit melebar }\end{array}$ \\
\hline 12 & Dayung & 168 & - & - & Sda & $\begin{array}{l}\text { Bagian dayung yang lebar dan } \\
\text { pipih masih utuh }\end{array}$ \\
\hline
\end{tabular}

Tabel 7. Gasing

\begin{tabular}{|c|c|c|c|c|c|c|c|}
\hline \multirow{2}{*}{ No } & \multirow{2}{*}{ Bentuk } & \multicolumn{4}{|c|}{ Ukuran $(\mathrm{cm})$} & \multirow{2}{*}{ Bahan/Fungsi } & \multirow{2}{*}{ Keterangan } \\
\hline & & $\begin{array}{l}\text { Panjang } \\
\text { Badan }\end{array}$ & $\begin{array}{c}\text { Tebal } \\
\text { Ujung Atas }\end{array}$ & $\begin{array}{c}\text { Diameter } \\
\text { Badan }\end{array}$ & Lebar & & \\
\hline 1 & Berbentuk jantung & 10 & $\begin{array}{l}0,5 \text { (bagian rata); } \\
1 \text { (bagian runcing) }\end{array}$ & 7,5 & 3 & $\begin{array}{l}\text { Kayu ulin, sebagai } \\
\text { alat permainan } \\
\text { gasing }\end{array}$ & $\begin{array}{l}\text { Bentuk ujung bagian atas dan } \\
\text { bawah meruncing }\end{array}$ \\
\hline 2 & Berbentuk jantung & 7 & 1 (bagian rata) & 5,5 & - & Sda & $\begin{array}{l}\text { Bentuk ujung bagian atas rata, } \\
\text { sedang bagian bawah } \\
\text { runcing }\end{array}$ \\
\hline 3 & Berbentuk jantung & 6 & $\begin{array}{l}0,5 \text { (bagian rata); } \\
1 \text { (bagian runcing }\end{array}$ & 5 & 2 & Sda & $\begin{array}{l}\text { Bentuk ujung bagian atas dan } \\
\text { bawah meruncing }\end{array}$ \\
\hline 4 & Berbentuk jantung & 7,5 & 1 (bagian rata) & 5 & 2 & Sda & $\begin{array}{l}\text { Bentuk ujung bagian atas rata, } \\
\text { bagian bawah runcing }\end{array}$ \\
\hline 5 & Berbentuk jantung & 7,5 & - & 7 & 3 & Sda & Bagian ujung tidak ada \\
\hline 6 & Berbentuk jantung & 4,5 & $\begin{array}{l}0,8 \text { (bagian rata); } \\
0,6 \text { (bagian runcing) }\end{array}$ & 4 & 1,5 & Sda & $\begin{array}{l}\text { Bentuk ujung bagian atas rata, } \\
\text { bagian bawah runcing }\end{array}$ \\
\hline 7 & Berbentuk jantung & 5,5 & $\begin{array}{l}0,8 \text { (bagian rata); } \\
0,6 \text { (bagian runcing) }\end{array}$ & 5,5 & 2 & Sda & $\begin{array}{l}\text { Bentuk ujung bagian atas rata, } \\
\text { bagian bawah runcing }\end{array}$ \\
\hline 8 & Berbentuk jantung & 6 & 1 (bagian rata) & 6 & 1,2 & Sda & $\begin{array}{l}\text { Bentuk ujung bagian atas rata, } \\
\text { bagian bawah runcing }\end{array}$ \\
\hline
\end{tabular}


Tabel 8. Wadah Kayu

\begin{tabular}{|c|c|c|c|c|c|c|c|}
\hline \multirow{2}{*}{ No } & \multirow{2}{*}{ Bentuk } & \multicolumn{4}{|c|}{ Ukuran $(\mathrm{cm})$} & \multirow{2}{*}{ Bahan/Fungsi } & \multirow{2}{*}{ Keterangan } \\
\hline & & Tebal & $\begin{array}{l}\text { Tinggi } \\
\text { Lubang }\end{array}$ & $\begin{array}{c}\text { Diameter } \\
\text { Badan }\end{array}$ & $\begin{array}{l}\text { Diamater } \\
\text { Lubang }\end{array}$ & & \\
\hline 1 & cobek & 4,5 & 3,5 & 28,5 & 26 & $\begin{array}{l}\text { Kayu ulin, untuk } \\
\text { menghaluskan biji- } \\
\text { bijian }\end{array}$ & $\begin{array}{l}\text { Kondisinya relatif masih utuh, } \\
\text { meskipun permukaan sudah } \\
\text { banyak yang pecah }\end{array}$ \\
\hline 2 & cobek & 4 & 2 & 17,5 & 15,5 & Sda & Sda \\
\hline 3 & cobek & 6 & 4 & 31 & 23 & Sda & Sda \\
\hline 4 & $\begin{array}{l}\text { Mangkuk bentuk } \\
\text { mirip perahu kecil }\end{array}$ & 6 & 5 & 27 & 2 & $\begin{array}{l}\text { Kayu ulin, untuk } \\
\text { wadah makanan }\end{array}$ & Kondisi masih utuh \\
\hline 5 & ember & $\begin{array}{l}26 \\
\text { (tinggi) }\end{array}$ & 24 & 19 & 17 & $\begin{array}{l}\text { Kayu ulin, untuk } \\
\text { wadah bahan } \\
\text { (makanan) bisa } \\
\text { padatbisa juga cair }\end{array}$ & $\begin{array}{l}\text { Bagian permukaan ember } \\
\text { sudah retak dan pecah pada } \\
\text { beberapa bagian }\end{array}$ \\
\hline
\end{tabular}

Tabel 9. Artefak dari Logam

\begin{tabular}{|c|c|c|c|c|c|c|}
\hline \multirow[b]{2}{*}{ No } & \multirow{2}{*}{ Bentuk } & \multicolumn{3}{|c|}{ Ukuran $(\mathrm{cm})$} & \multirow{2}{*}{ Bahan/Fungsi } & \multirow{2}{*}{ Keterangan } \\
\hline & & Panjang & $\begin{array}{c}\text { Lebarl } \\
\text { Tebal }\end{array}$ & Diameter & & \\
\hline 1 & Perhiasan & 1,5 & 2 & - & $\begin{array}{l}\text { Emas, sebagai cincin (?), } \\
\text { sebenarnya terlalu kecil } \\
\text { untuk dipakai orang } \\
\text { dewasa }\end{array}$ & $\begin{array}{l}\text { Bentuk manusia setengah badan } \\
\text { dengan dua tangan masing2 } \\
\text { masing membawa senjata } \\
\text { (camara ?) kepalanya memakai } \\
\text { mahkaota dan memakai ikat } \\
\text { pinggang }\end{array}$ \\
\hline 2 & Perhiasan & 1,5 & 1 & - & Sda & $\begin{array}{l}\text { Berbentuk burung garuda } \\
\text { (lengkap dengan bagian kepala, } \\
\text { badan dan kaki), bagian tengah } \\
\text { terdapat tempat untuk } \\
\text { menempelkan batu berharga }\end{array}$ \\
\hline 3 & Perhiasan & - & 0,2 & 1,6 & Sda & Cincin ini berbentuk ulir \\
\hline 4 & Perhiasan & 0,8 & 0,74 & - & Sda & $\begin{array}{l}\text { Manik berbentuk piramida ganda } \\
\text { penggal }\end{array}$ \\
\hline 5 & Perhiasan & 0,75 & - & 1,1 & Sda & $\begin{array}{l}\text { Cincin dengan bentuk permukaan } \\
\text { atas bulat gepeng }\end{array}$ \\
\hline 6 & Perhiasan & 1,2 & - & 1 & Sda & $\begin{array}{l}\text { Cincin dengan hiasan meander } \\
\text { ( } 5 \text { bh) yang mengelilingi batu } \\
\text { warna hitam }\end{array}$ \\
\hline 7 & Perhiasan & 0,9 & - & 0,9 & Sda & $\begin{array}{l}\text { Cincin bulat dengan sedikit bagian } \\
\text { yang datar (sebagai hiasan?) }\end{array}$ \\
\hline 8 & Perhiasan & 0,6 & - & 0,5 & Sda & $\begin{array}{l}\text { Bagian dari sebuah patung, } \\
\text { mungkin merupakan bagian dari } \\
\text { kepala Budha yang digambarkan } \\
\text { dengan rambut yang membentuk } \\
\text { lingkaran-lingkaran kecil (?) }\end{array}$ \\
\hline 9 & Jimat & 1,2 & 1,2 & - & Sda & $\begin{array}{l}\text { Jimat ini berbentuk kotak } \\
\text { (bujursangkar) yang merupakan } \\
\text { lempengen emas yang dilengkapi } \\
\text { dengan hiasan geometris berupa } \\
\text { garis lurus dan garis lengkung, } \\
\text { membentuk sebuah hiasan }\end{array}$ \\
\hline
\end{tabular}




\begin{tabular}{|l|l|l|l|l|l|l|}
\hline \multirow{2}{*}{ No } & \multirow{2}{*}{ Bentuk } & \multicolumn{3}{|c|}{ Ukuran (cm) } & \multirow{2}{*}{ Bahan/Fungsi } & \multicolumn{1}{c|}{ Keterangan } \\
\cline { 3 - 6 } & Panjang & $\begin{array}{c}\text { Lebar/ } \\
\text { Tebal }\end{array}$ & Diameter & & \\
\hline 10 & Perhiasan & 5,7 & 1,3 & - & Timah (?) & $\begin{array}{l}\text { Bentuk seperti gelang, dengan } \\
\text { ujung yang tidak menjadi satu } \\
\text { (bertumpuk) }\end{array}$ \\
\hline 12 & Perhiasan & 2,9 & 0,5 & 3,2 & Sda & $\begin{array}{l}\text { Bentuk seperti gelang, dengan } \\
\text { ujung yang tidak menjadi satu } \\
\text { (bertumpuk) }\end{array}$ \\
\hline 13 & Perhiasan (?) & - & 1 & 2,5 & Sda & $\begin{array}{l}\text { Gelang berbentuk hati ini bagian } \\
\text { ujungnya juga tidak bersatu }\end{array}$ \\
\hline 14 & Genta (?) & 5,4 & 0,7 & 5,6 & Sda & $\begin{array}{l}\text { Manik berbentuk bulat dempak, } \\
\text { kemungkinan juga bisa berfungsi } \\
\text { sebagai pemberat jala (?) }\end{array}$ \\
\hline
\end{tabular}

Tabel 10. Manik-manik

\begin{tabular}{|c|l|c|c|l|l|}
\hline \multirow{2}{*}{ No } & \multicolumn{1}{|c|}{ Bentuk } & \multicolumn{2}{c|}{ Ukuran $(\mathrm{mm})$} & \multirow{2}{*}{ Bahan/Fungsi } & \multirow{2}{*}{ Keterangan } \\
\cline { 2 - 4 } & & Panjang & Diameter & & \\
\hline 1 & Manik silinder & 19 & 11 & Karnelian & Warna coklat merah \\
\hline 2 & Manik silinder & 23 & 13 & Karnelian & Warna coklat merah \\
\hline 3 & Manik kerucut ganda persegi enam & 15 & 9 & Karnelian & Warna coklat merah \\
\hline 4 & Manik bentuk elips & 10 & 9 & Karnelian & Warna coklat merah jumlah2 buah \\
\hline 5 & Manik bentuk bulat dempak & 7 & 8 & Karnelian & $\begin{array}{l}\text { Warna coklat merah, jumlah 23 } \\
\text { buah }\end{array}$ \\
\hline 6 & Manik bentuk bulat dempak & 9 & 10 & Karnelian & $\begin{array}{l}\text { Warna coklat merah, jumlah 18 } \\
\text { buah }\end{array}$ \\
\hline 7 & Manik bentuk bulat dempak & 6 & 7 & Karnelian & $\begin{array}{l}\text { Warna coklat merah, jumlah 15 } \\
\text { buah }\end{array}$ \\
\hline 8 & Manik bentuk cakram & 4 & 11 & Karnelian & Warna coklat tua \\
\hline 9 & Manik bentuk bulat dempak & 9 & 10 & Karnelian & Putih coklat, jumlah 2 buah \\
\hline 10 & Manik bentuk bulat dempak & 9 & 10 & Karnelian & Warna putih abu-abu \\
\hline 11 & Manik bentuk bulat dempak & 15 & 15 & Karnelian & Warna coklat \\
\hline 12 & Manik bentuk bulat dempak & 7 & 8 & Karnelian & Warna coklat muda \\
\hline 13 & Manik bentuk tong & 9 & 11 & Kaca & Warna coklat merah \\
\hline 14 & Manik berfacet banyak & 3 & 10 & Kaca & Warna merah tua \\
\hline 15 & Manik beruas & 11 & 9 & Kaca & Warna merah \\
\hline 16 & Manik bentuk bulat dempak & 6 & 7 & Kaca & Warna hijau \\
\hline 17 & Manik bentuk tong & 8 & 9 & Kaca & Warna hijau \\
\hline 18 & Manik bentuk tong & 7 & 11 & Kaca & warna hijau bening \\
\hline
\end{tabular}




\begin{tabular}{|c|c|c|c|c|c|}
\hline \multirow[b]{2}{*}{ No } & \multirow{2}{*}{ Bentuk } & \multicolumn{2}{|c|}{ Ukuran (mm) } & \multirow{2}{*}{ Bahan/Fungsi } & \multirow{2}{*}{ Keterangan } \\
\hline & & Panjang & Diameter & & \\
\hline 19 & Manik bentuk bulat dempak & 10 & 11 & Kaca & Warna Hijau bening \\
\hline 20 & Manik kerucut ganda persegi enam & 14 & 14 & Batuan hablur & Warna putih \\
\hline 21 & Manik bentuk bulat dempak & 16 & 16 & Batuan hablur & Warna putih \\
\hline 22 & Manik bentuk bulat dempak & 12 & 12 & Batuan hablur & Warna putih, jumlah 23 buah \\
\hline 23 & Manik bentuk bulat dempak & 8 & 8 & Batuan hablur & Warna putih, jumlah 10 buah \\
\hline 24 & Manik bentuk bulat dempak & 13 & 13 & Kaca & Warna kuning \\
\hline 25 & Manik bentuk tong & 13 & 10 & Kaca & Warna kuning, jumlah 66 buah \\
\hline 26 & Manik bentuk tong ganda & 13 & 11 & Kaca & Warna kuning, jumlah 26 buah \\
\hline 27 & Manik bentuk tong & 14 & 11 & Kaca & Warna kuning keemasan \\
\hline 28 & Manik bentuk tong & 7 & 8 & Kaca & $\begin{array}{l}\text { Warna kuning keemasan, } \\
\text { berjumlah } 12 \text { buah }\end{array}$ \\
\hline 29 & Manik bentuk segi empat & 12 & 6 & Kaca & Warna kuning keemasan \\
\hline 30 & Manik bentuk tong & 5 & 6 & Kaca & $\begin{array}{l}\text { Warna kuning keemasan, } \\
\text { nerjumlah } 4 \text { buah }\end{array}$ \\
\hline 31 & Manik bentuk tong ganda & 12 & 7 & Kaca & Warna kuning keemasan \\
\hline 32 & Manik bentuk silinder ganda & 14 & 5 & Kaca & Warna kuning keemasan \\
\hline 33 & Manik bentuk tong & 7 & 9 & Kaca & Warna biru tua, jumlah 14 buah \\
\hline 34 & Manik kerucut ganda segi empat & 18 & 7 & Kaca & Warna biru tua \\
\hline 35 & Manik kerucut ganda segi empat & 14 & 7 & Kaca & Warna biru tua, jumlah 2buah \\
\hline 36 & Manik bentuk tong ganda & 14 & 7,5 & Kaca & Warna biru tua, jumlah 2 buah \\
\hline 37 & Manik bentuk tong & 12 & 11 & Kaca & Warna biru tua, jumlah 3 buah \\
\hline 38 & Manik bentuk tong & 11 & 8 & Kaca & Warna biru tua \\
\hline 39 & Manik bentuk tong & 11 & 9 & Kaca & Warna biru tua \\
\hline 40 & Manik bentuk silinder & 7 & 10 & Kaca & Warna biru tua, jumlah 4 buah \\
\hline 41 & Manik bentuk silinder & 6 & 8 & Kaca & Warna biru tua \\
\hline 42 & Manik bentuk bulat dempak & 6 & 6 & Kaca & Warna biru tua, jumlah 2 buah \\
\hline 43 & Manik bentuk silinder & 6 & 7 & Kaca & Warna biru tua, jumlah 2 buah \\
\hline 44 & Manik bentuk tong ganda & 12 & 8 & Kaca & $\begin{array}{l}\text { Warna biru muda, dua buah manik } \\
\text { jadi satu }\end{array}$ \\
\hline 45 & Manik bentuk tong & 9 & 5 & Kaca & $\begin{array}{l}\text { Warna biru muda, dua buah manik } \\
\text { jadi satu, jumlah } 4 \text { buah }\end{array}$ \\
\hline 46 & Manik bentuk tong & 29 & 4 & Kaca & $\begin{array}{l}\text { Warna biru muda, lima buah manik } \\
\text { jadi satu, jumlah } 1 \text { buah }\end{array}$ \\
\hline 47 & Manik bentuk segi empat & 25 & 5 & Kaca & $\begin{array}{l}\text { Warna biru muda, empat buah } \\
\text { manik jadi satu, jumlah } 1 \text { buah }\end{array}$ \\
\hline 48 & Manik bentuk tong & 9 & 6 & Kaca & Coklat, jumlah empat buah \\
\hline 49 & Manik bentuk tong ganda & 11 & 4 & Kaca & Warna coklat, jumlah 4 buah \\
\hline 50 & Manik bentuk silinder ganda & 9 & 7 & Kaca & Warna coklat, jumlah 1 buah \\
\hline 51 & Manik bentuk tong & 10 & 7 & Kaca & Warna coklat \\
\hline 52 & Manik kerucut ganda segi empat & 6 & 6 & Kaca & Warna coklat, jumlah 3 buah \\
\hline 53 & Manik kerucut ganda segi empat & 12 & 6 & Kaca & $\begin{array}{l}\text { Warna coklat dilur dan hitam di } \\
\text { dalam }\end{array}$ \\
\hline 54 & Manik bentuk tong ganda & 9 & 5 & Kaca & $\begin{array}{l}\text { Warna coklat dengan garis coklat } \\
\text { tua }\end{array}$ \\
\hline
\end{tabular}




\begin{tabular}{|c|c|c|c|c|c|}
\hline \multirow{2}{*}{ No } & \multirow[b]{2}{*}{ Bentuk } & \multicolumn{2}{|c|}{ Ukuran (mm) } & \multirow{2}{*}{ Bahan/Fungsi } & \multirow{2}{*}{ Keterangan } \\
\hline & & Panjang & Diameter & & \\
\hline 55 & Manik bentuk silinder & 10 & 8 & Kaca & $\begin{array}{l}\text { Manik pelangi, warna hitam } \\
\text { dengan garis vertikal warna } \\
\text { merah, jumlah } 1 \text { buah }\end{array}$ \\
\hline 56 & Manik bentuk cakram & 6 & 8 & Kaca & Sda, jumlah 2 buah \\
\hline 57 & Manik bentuk silinder & 6 & 6,5 & Kaca & Sda, jumlah 1 buah \\
\hline 58 & Manik bentuk cakram & 8 & 12 & Kaca & $\begin{array}{l}\text { Manik pelangi, warna merah, } \\
\text { hijau, kuning, biru }\end{array}$ \\
\hline 59 & Manik bentuk cakram & 3 & 6 & Kaca & $\begin{array}{l}\text { Manik pelangi, warna biru, puth, } \\
\text { jumlah } 5 \text { buah }\end{array}$ \\
\hline 60 & Manik bentuk cakram & 4 & 6 & Kaca & $\begin{array}{l}\text { Manik pelangi, warna biru, putih, } \\
\text { jumlah } 2 \text { buah }\end{array}$ \\
\hline 61 & Manik bentuk cakram & 6 & 7 & Kaca & $\begin{array}{l}\text { Manik pelangi, warna hitam } \\
\text { kuning, jumlah tiga buah }\end{array}$ \\
\hline 62 & Manik bentuk cakram & 6 & 8 & Kaca & Manik pelangi, hijau, hitam, putih \\
\hline 63 & Manik bentuk silinder & 8 & 8 & Kaca & $\begin{array}{l}\text { Manik pelangi, warna coklat, } \\
\text { putih, merah }\end{array}$ \\
\hline 64 & Manik beruas & 13 & 9 & Kaca & $\begin{array}{l}\text { Manik pelangi, warna coklat, putih, } \\
\text { merah }\end{array}$ \\
\hline 65 & Manik bentuk silinder & 8 & 5 & Kaca & $\begin{array}{l}\text { Manik mata, warna coklat, kuning, } \\
\text { puth }\end{array}$ \\
\hline 66 & Manik bentuk silinder & 9 & 6 & Kaca & $\begin{array}{l}\text { Manik mata, warna hijau dan } \\
\text { kuning (garis) }\end{array}$ \\
\hline 67 & Manik bentuk elips & 8 & 8 & Kaca & $\begin{array}{l}\text { Manik pelangi, wrna orange, } \\
\text { bergaris putih dam biru }\end{array}$ \\
\hline 68 & Manik bentuk tabung & 11 & 6 & Kaca & $\begin{array}{l}\text { Manik mata, warna hijau dan garis } \\
\text { putih, warna mata merah dan } \\
\text { kuning }\end{array}$ \\
\hline 69 & $\begin{array}{l}\text { Manik berukuran sangat } \\
\text { kecil bentuk cakram dan } \\
\text { silinder }\end{array}$ & $<2$ & $<2$ & Kaca & $\begin{array}{l}\text { Warna ada beberapa macam, } \\
\text { yaitu coklat, kuning, hijau, dan biru }\end{array}$ \\
\hline
\end{tabular}

Tabel 11. Botol Belanda

\begin{tabular}{|c|l|l|c|c|l|l|}
\hline \multirow{2}{*}{ No } & \multirow{2}{*}{ Bentuk } & \multicolumn{2}{|c|}{ Ukuran (cm) } & \multirow{2}{*}{ Bahan/Fungsi } & \multicolumn{1}{c|}{ Keterangan } \\
\cline { 3 - 6 } & Panjang & $\begin{array}{c}\text { Lebar/ } \\
\text { Tebal }\end{array}$ & Diameter & \\
\hline 1 & Botol berleher pendek & 30 & 8,3 & $\begin{array}{c}3 \text { (bagian } \\
\mathrm{m} \text { u l u t/ } \\
\text { atas) }\end{array}$ & Stoneware & $\begin{array}{l}\text { Warna coklat dengan tulisan pada } \\
\text { bagian badannya, yaitu } \\
\text { "Ervenlucas Bols't Lootsje } \\
\text { Amsterdam 1 liter (dituliskan pada } \\
\text { bahu botol), jumlah dua buah }\end{array}$ \\
\hline 2 & Botol berleher pendek & 27,5 & 8 & $\begin{array}{l}3 \text { (bagian } \\
\text { m u l u t/ } \\
\text { atas) }\end{array}$ & Stoneware & $\begin{array}{l}\text { Warna coklat dengan tulisan pada } \\
\text { bagian badannya, yaitu } \\
\text { "ULSTKAMP ZOOM MOLYN } \\
\text { ROTTERDAM * C.4 (dituliskan } \\
\text { pada bahu botol), jumlah 1 buah. } \\
\text { Pada salah satu bagin bahu botol } \\
\text { terdapat pegangan berbentuk } \\
\text { melingkar }\end{array}$ \\
\hline
\end{tabular}




\begin{tabular}{|c|c|c|c|c|c|c|}
\hline \multirow{2}{*}{ No } & \multirow{2}{*}{ Bentuk } & \multicolumn{3}{|c|}{ Ukuran (cm) } & \multirow{2}{*}{ Bahan/Fungsi } & \multirow{2}{*}{ Keterangan } \\
\hline & & Panjang & $\begin{array}{c}\text { Lebarl } \\
\text { Tebal }\end{array}$ & Diameter & & \\
\hline 3 & Botol & 17 & 70 & $\begin{array}{l}2,5 \\
\text { (bagian } \\
\text { mulut } \\
\text { botol) }\end{array}$ & Kaca bening & $\begin{array}{l}\text { Warna hijau, dilengkapi dengan } \\
\text { tutup wrna putih terikat dengan } \\
\text { kawat besi. Terdapat tulisan } \\
\text { melingkari botol, yaitu HELLFACH } \\
\text { \& COMERK BOLA SOERABAIA. } \\
\text { Jumlah dua buah }\end{array}$ \\
\hline 4 & Botol & 29,7 & 9 & $\begin{array}{l}3 \\
\text { (bagian } \\
\text { mulut) }\end{array}$ & Sda & $\begin{array}{l}\text { Warna hijau, tidak bertutup, dasar } \\
\text { botol bagian tengah ada yang } \\
\text { masuk ke badan (sepanjang } 5,5 \\
\mathrm{~cm} \text { ), jumlah dua buah }\end{array}$ \\
\hline 5 & Botol & 21 & 7,8 & $\begin{array}{l}2,8 \\
\text { (bagian } \\
\text { mulut) }\end{array}$ & Sda & $\begin{array}{l}\text { Warna putih bening, tidak } \\
\text { bertutup, dasar botol bagian } \\
\text { tengah berbentuk cembung, } \\
\text { masuk kebagian badan botol } \\
\text { sepanjang } 2,5 \mathrm{~cm} \text {, jumlah } 1 \text { buah }\end{array}$ \\
\hline 6 & Botol berleher pendek & 29 & $\begin{array}{l}11 \\
\text { (bagian } \\
\text { bahu); } \\
7,5 \\
\text { (bagian } \\
\text { dasar) }\end{array}$ & $\begin{array}{l}2 \\
\text { (bagian } \\
\text { mulut) }\end{array}$ & Kaca & $\begin{array}{l}\text { Warna hitam, tidak bertutup, } \\
\text { bagian bahu lebih lebar dari pada } \\
\text { bagian dasar, badan botol } \\
\text { cenderung kotak bukan membulat }\end{array}$ \\
\hline 7 & Guci bentuk silinder & 20 & 12,5 & $\begin{array}{l}10,5 \\
\text { (bagian } \\
\text { mulut } \\
\text { luar); } \\
8 \\
\text { (bagian } \\
\text { mulut } \\
\text { dalam) }\end{array}$ & Porselen & $\begin{array}{l}\text { Warna glasir krem dengan garis } \\
\text { biru melingkar pada bagian bahu } \\
\text { dan badan (bagian bawag, diatas } \\
\text { dasar guci). Terdapat tulisan } \\
\text { W.HOOGENSTRAATEN X C } 0 \\
\text { LEIDEN }\end{array}$ \\
\hline
\end{tabular}

Tabel 12. Kendi Gerabah

\begin{tabular}{|c|c|c|c|c|c|c|}
\hline \multirow[b]{2}{*}{ No } & \multirow[b]{2}{*}{ Bentuk } & \multicolumn{3}{|c|}{ Ukuran (cm) } & \multirow{2}{*}{ Bahan/Fungsi } & \multirow{2}{*}{ Keterangan } \\
\hline & & Panjang & $\begin{array}{c}\text { Lebar/ } \\
\text { Tebal }\end{array}$ & Diameter & & \\
\hline 1 & Kendi bercerat satu & 12 & 15 & $\begin{array}{l}10 \\
\text { (mulut); } \\
6 \text { (dasar) }\end{array}$ & Gerabah (tanah liat) & $\begin{array}{l}\text { Warna krem (coklat muda), } \\
\text { dengan leher pendek dan tepian } \\
\text { relatif besar (bagian mulut lebih } \\
\text { lebar daripada dasar), berdasar } \\
\text { rata. Badan bulat dan pendek }\end{array}$ \\
\hline 2 & Kendi bercerat ganda (2) & $\begin{array}{l}15 \\
\text { (badan } \\
\text { d a n } \\
\text { dasar); } \\
1 \\
\text { (paniang } \\
\text { cerat) }\end{array}$ & $\begin{array}{l}16 \\
\text { (badan); } \\
8,2 \\
\text { (dasar) }\end{array}$ & $\begin{array}{l}4,5 \text { pada } \\
\text { bagian } \\
\text { d a s a r } \\
\text { I e h e r } \\
\text { (luar); } \\
\text { 2 (bagian } \\
\text { dalam) }\end{array}$ & Gerabah (tanah liat) & $\begin{array}{l}\text { Warna putih, sudah tidak } \\
\text { lengkaplagi, bagian leher dan } \\
\text { mulut kendi sudah hilang, posisi } \\
\text { dua buah cerat menyatu. }\end{array}$ \\
\hline
\end{tabular}


Tabel 13. Fragmen Keramik Asing (Temuan Penduduk)

\begin{tabular}{|c|c|c|c|c|c|c|}
\hline No & Bahan & Bentuk & Warna Glasir & Diameter (cm) & Pola Hias & Asal \\
\hline 1 & Porselen & mangkuk & seladon & $\begin{array}{l}6 \text { (dasar); } \\
16 \text { (tepian) }\end{array}$ & Lundang-lundang & Yuan \\
\hline 2 & Porselen & mangkuk & seladon & $\begin{array}{l}4 \text { (dasar); } \\
9 \text { (tepian) }\end{array}$ & - & Yuan \\
\hline 3 & Porselen & mangkuk & seladon & - & Ikan (sgrafito) & Yuan Akhir \\
\hline 4 & Batuan & mangkuk & hijau tipis & - & Teratai & Vietnam (?) \\
\hline 5 & Porselen & piring & seladon & $\begin{array}{l}6 \text { (dasar); } \\
16 \text { (tepian }\end{array}$ & Teratai (sgrafito) & Yuan Akhir \\
\hline 6 & Porselen & piring & seladon & - & Geometris (relief) & Ming \\
\hline 7 & Porselen & piring & putih tipis & - & - & Ming \\
\hline 8 & Porselen & vas & $\begin{array}{l}\text { hijau muda, } \\
\text { putih }\end{array}$ & - & - & Yuan \\
\hline 9 & Batuan & vas & pudar/hilang & 10 (tepian) & - & Yuan \\
\hline 10 & Porselen & vas & hijau tipis & 7 (dasar) & Geometris (relief) & Ming \\
\hline 11 & Batuan & tempayan & hijau & 6,4 (dasar) & - & Yuan \\
\hline 12 & Batuan & tempayan & hitam & - & Geometris & Song \\
\hline 13 & Batuan & tempayan & - & - & Geometris & Song \\
\hline 14 & Porselen & $\begin{array}{l}\text { tutup } \\
\text { mangkuk }\end{array}$ & seladon & - & Lundang-lundang & Yuan \\
\hline 15 & Porselen & tutup cepuk & seladon & - & Bersegi banyak & Yuan \\
\hline 16 & Batuan & botol & - & - & - & Song Akhir \\
\hline 17 & Porselen & botol & coklat & - & - & Eropa \\
\hline 18 & Porselen & mangkuk & putih biru & - & Bunga, geometris & Qing \\
\hline
\end{tabular}

